\title{
A Review on Studies of Heavy Metal Determination in Mackerel and Tuna (Family- Scombridae) Fishes
}

\author{
Quratulan AHMED $^{1} \quad$ Levent BAT $^{2} \quad$ Aysah ÖZTEKIN $^{2} \quad$ Qadeer MOHAMMAD ALI $^{1}$ \\ ${ }^{I}$ The Marine Reference Collection and Resources Centre, University of Karachi, Karachi, 75270 PAKISTAN \\ ${ }^{2}$ Department of Hydrobiology, Fisheries Faculty, Sinop University, 57000 Sinop, TURKEY
}

\begin{abstract}
Many chemicals especially heavy metals that are exist in fish are essential for human life at low amounts, but can be toxic at high amounts. Other chemicals such as $\mathrm{Hg}, \mathrm{As}, \mathrm{Cd}$ and $\mathrm{Pb}$ have not any essential function in biota and are toxic even at very low amounts when ingested for a long period. The aim of this review is to compare and evaluate heavy metal levels in commercial fish species from the Arabian Sea and coastline in other seas. In this review, Mackerels, Tunas and Bonitos species, the most commercial of Scombridae family, were chosen. The state of the metal pollution levels of these fishes is revealed under the light of the literature. The chemicals, some of which are the most important heavy metals such as $\mathrm{Zn}, \mathrm{Fe}, \mathrm{Cu}, \mathrm{Pb}, \mathrm{Cd}, \mathrm{Hg}, \mathrm{As}, \mathrm{Cr}$ and $\mathrm{Mn}$ were chosen and their amounts in commercial fish were evaluated.

Most of studies showed that essential metals in fish species are much high, but the quantities of non-essential metals in edible tissues of fish are found to be less. This review has shown that fish are used as bio-monitoring in heavy metal pollution. It is suggested that such investigations should be continuous in terms of both human health and determination of metal pollution of our coasts.
\end{abstract}

Keywords: Heavy metals, tuna and mackerel fishes

How to cite: Ahmed, Q., Bat, L., Öztekin, A. \& Mohammad Ali, Q. (2018). A Review on Studies of Heavy Metal Determination in Mackerel and Tuna (FamilyScombridae) Fishes. J. Anatolian Env. and Anim. Sciences, 3(3), 107-123.

\section{Uskumru ve Ton (Familya-Scombridae) Balıklarında Ağır Metal Çalışmaları Üzerine Bir Derleme}

Öz: Özellikle balıklarda bulunan birçok kimyasal madde, düşük miktarlarda insan yaşamı için çok önemlidir, ancak yüksek miktarlarda zehirli olabilir. $\mathrm{Hg}$, As, Cd ve Pb gibi diğer kimyasalların canlıda önemli bir işlevi yoktur ve uzun bir süre çok düşük miktarlarda bile gıda yoluyla alınırsa zehirlidir. Bu derlemenin amacı özellikle Arap Denizi ve diğer denizlerdeki klyı şeridinden yakalanan ticari balık türlerindeki ağır metal seviyelerini karşılaştırmak ve değerlendirmektir. Bu derlemede, Scombridae ailesinin en ticari balıkları olan uskumru, tonbalı̆̆ ve palamut türleri seçilmiştir. Bu balıkların metal kirlilik düzeylerinin durumu, literatür ışığında ortaya konulmuştur. Zn, $\mathrm{Fe}, \mathrm{Cu}, \mathrm{Pb}$, $\mathrm{Cd}, \mathrm{Hg}, \mathrm{As}$, Cr ve Mn gibi en önemli ă̆ır metaller olan kimyasallar seçilmiş ve ticari balıklardaki miktarları değerlendirilmiştir.

Çalışmaların çoğu, balık türlerindeki gerekli metallerin çok yüksek, ancak balıkların yenilebilir dokularındaki gerekli olmayan metallerin miktarlarının daha az olduğu bulunmuştur. Bu derleme balıkların ă̆ır metal kirliliğinde biyo-izleme olarak kullanıldı̆̆ını göstermiştir. Bu tür araştırmaların hem insan sağlı̆̆ı hem de klyılarımızdaki metal kirliliğinin belirlenmesi açısından sürekli olması önerilmektedir.

Anahtar sözcükler: Ağır metal, ton ve uskumru balıkları

Attf yapmak için: Ahmed, Q., Bat, L., Öztekin, A. \& Mohammad Ali, Q. (2018). Uskumru ve Ton (Familya-Scombridae) Balıklarında Ağır Metal Çalışmaları Üzerine Bir Derleme. Anadolu Çev. ve Hay. Dergisi, 3(3), 107-123.

\section{INTRODUCTION}

The family Scombridae, Mackerels, Tunas, and Bonitos, includes some of the world's most popular food and sport fishes. Scombrids are, for the most part, pelagic (open-ocean) fishes living in tropical and subtropical seas. Some species make seasonal forays into cool temperate or cold waters. Some, especially the smaller mackerels, remain near coastlines, while many others roam deeper waters. Most Scombrids are schooling fishes, but some can be found singly. They follow a nomadic lifestyle, sometimes migrating over distances. For some groups, migrations are seasonal and may be determined by water temperature (Wheeler, 1985; Helfmen et al., 1997). Pakistan has a considerably large tuna and mackerel industry in which is based on gill-netting operation. Pakistani tuna boats operate mainly in offshore Pakistan waters and used to land entire catch in wet-salted form for onward export to Sri Lanka. These boats, now deliver their catch directly or indirectly to tuna canneries in Iran in chilled and frozen form. A small quantity of tuna is still landed in wet salted form which is exported to its traditional market in Sri Lanka. Total annual tuna production of Pakistan is estimated to be around 40,000 $\mathrm{m}$. tons. Despite its importance, tuna fisheries of Pakistan is marred with a number of issues, the most important being the high bycatch rate because of use of pelagic gill-netting method. High post-harvest loses are another serious issue faced by the tuna fisheries of Pakistan. Eight species of tuna 
are known from Pakistani waters. These include kawakawa, frigate, bullet, skipjack, long-tail, bigeye, yellowfin tunas and stripped bonitos.

European Food Safety Authority concludes that fish is a source of energy and protein with high biological value and provides n-3 long-chain polyunsaturated fatty acids, and is a component of dietary patterns associated with good health. It is recommended that a minimum of two servings of fish per week for older children and adults and up to 3-4 servings for pregnant. Moreover, such quantities have also been associated with a lower risk of coronary heart disease mortality in adults. However, it should be noted that no additional benefits on neurodevelopmental outcomes and no benefit on coronary heart disease mortality risk might be expected at higher intakes (EFSA, 2012a, b, c). It should not also be forgotten that fish are natural water inhabitants, thus they cannot avoid the toxic effects of heavy metals.

Karachi coast is a very important coast for its dimensions and economic activity. There are over 11,000 industrial units (CDGK, 2012) present, more than 2,000 units in Federal-B-Area, 2,571 units in Korangi zone, 2,000 units in North Karachi, 1,200 units in Landhi zone, and 4,000 units in Mangopir zone in Karachi. By the Karachi coastline ever growing pollution level, which is linked to the increase of the shipping industry through the Karachi port, is severely contaminating the mangrove, forests and marine life. The dumping of wastes in the coast provides a major source of heavy metal input (Khattak et al., 2012; Mukhtar \& Hannan, 2012). Little data documented of heavy metals in mackerel and tuna fishes in Pakistan. The important sources of heavy metals pollution are industrial activities and dumping of land-based wastes into the river and coasts of the sea. Especially in Pakistan and other countries such as India and Bangladesh most of industries are converged on the riverbanks of big cities. Not only these countries but all the coastal countries are exposed to heavy metal pollution. In the coastal areas heavy metal contamination is found in seawater, sediment and aquatic organisms, causing a health risk.

Of the 92 naturally occurring elements, approximately 30 metals and metalloids are potentially toxic to humans such as $\mathrm{Hg}, \mathrm{Cd}, \mathrm{Pb}, \mathrm{Cr}, \mathrm{Mn}, \mathrm{Ni}, \mathrm{Cu}, \mathrm{As}$. The term of heavy metals having an atomic weight higher than 40.04 (Appenroth, 2010) has been replaced in years by a classification scheme that considers their chemistry rather than relative density (Nieboer \& Richardson, 1980). They are chemical elements with a specific gravity that is at least 5 times the specific gravity of water which is 1 at $4^{\circ} \mathrm{C}$ (Appenroth, 2010). Separation of some essential and nonessential metal ions of importance as pollutants into class A (oxygen-seeking) including $\mathrm{Ca}, \mathrm{Mg}, \mathrm{Mn}, \mathrm{K}, \mathrm{Sr}, \mathrm{Na}$, class $\mathrm{B}$ (sulphur or nitrogen-seeking) including $\mathrm{Zn}, \mathrm{Pb}, \mathrm{Fe}, \mathrm{Cr}$, Co, $\mathrm{Ni}, \mathrm{As}, \mathrm{V}$ and borderline elements including $\mathrm{Cd}, \mathrm{Cu}, \mathrm{Hg}, \mathrm{Ag}$ based on the classification scheme of Nieboer and Richardson (1980).

Studies on heavy metals in fish mainly tuna and mackerel: Heavy metal levels in edible tissue of Mackerels, Tunas, and Bonitos in mainly the Arabian Sea coastline in other seas were given in Table 1.

Adams and McMichael (2007) studied that total mercury concentrations were analyzed in dorsal muscle tissue from 279 king mackerel, Scombemmorus cavalla, and from 580 Spanish mackerel, S. maculates. All fish sample were collected from offshore and coastal waters of the Atlantic Ocean and Gulf of Mexico in south-eastern USA. Mercury levels in king mackerel ranged from 0.19 to 3.6 ppm $($ mean $=0.94 \mathrm{ppm} ;$ median $=0.65 \mathrm{ppm})$ on the Atlantic coast and from 0.18 to $4.0 \mathrm{ppm}$ (mean $=1.51 \mathrm{ppm}$; median $=1.3 \mathrm{ppm}$ ) on the gulf coast. Total mercury levels for Spanish mackerel ranged from 0.04 to $1.3 \mathrm{ppm}$ ( mean $=0.32$ $\mathrm{ppm}$; median $=0.27 \mathrm{ppm})$ on the Atlantic coast and from 0.09 to $3.2 \mathrm{ppm}($ mean $=0.53 \mathrm{ppm} ;$ median $=0.44 \mathrm{ppm})$ on the gulf coast.

Agusa et al. (2007) concentrations of 20 trace elements were determined in muscle and liver of 34 species of marine fish collected from coastal areas of Cambodia, Indonesia, Malaysia and Thailand. Large regional difference was observed in the levels of trace elements in the liver of one fish family (Carangidae). The highest mean concentration was observed in fish from the Malaysian coastal waters for $\mathrm{V}, \mathrm{Cr}, \mathrm{Zn}, \mathrm{Pb}$ and $\mathrm{Bi}$ and those from the Java Sea side of Indonesia for $\mathrm{Sn}$ and $\mathrm{Hg}$. To assess the health risk to the Southeast Asian populations from consumption of fish, intake rates of trace elements were estimated. Some marine fish showed $\mathrm{Hg}$ levels higher than the guideline values by U.S. Environmental Protection Agency and Joint FAO/WHO Expert Committee on Food Additives (JECFA). This suggests that consumption of these fish may be hazardous to the people. Intake of mercury through consumption of some marine fish species might be hazardous to the people in Southeast Asia.

Ahmed and Abdallah (2008) investigated the concentrations of metals $(\mathrm{Cd}, \mathrm{Pb}, \mathrm{Cu}, \mathrm{Cr}, \mathrm{Zn})$ in fishes Sardinella aurita, Alepes djedaba, Siganus luridus, Siganus rivulatus, Sphyraena chrysotoenia and Scomberomorus commerson collected from El-Mex Bay. The heavy metal concentrations were recorded in muscles of fishes. Zinc was the highest (up to $57 \mathrm{mg} / \mathrm{kg}$ ) followed by $\mathrm{Cr}, \mathrm{Cu}, \mathrm{Pb}$ and $\mathrm{Cd}$ in those fish species. 
Table 1. Heavy metal levels in edible tissue of Mackerels, Tunas, and Bonitos

Tablo 1. Uskumru, Ton ve Palamut balıklarının yenilebilir dokularındaki ağır metal seviyeleri

\begin{tabular}{|c|c|c|c|c|c|c|c|c|c|c|c|c|c|}
\hline \multirow{2}{*}{ Species } & \multirow{2}{*}{ Location } & \multirow{2}{*}{$\begin{array}{l}\text { d.w./ } \\
\text { w.w. }\end{array}$} & \multirow{2}{*}{ unit } & \multicolumn{9}{|c|}{ Metals } & \multirow{2}{*}{ References } \\
\hline & & & & $\mathbf{Z n}$ & $\mathrm{Fe}$ & $\mathrm{Cu}$ & $\mathbf{P b}$ & $\mathrm{Cd}$ & $\mathrm{Hg}$ & As & $\mathrm{Cr}$ & Mn & \\
\hline Scomberomorus cavalla & \multirow{2}{*}{$\begin{array}{l}\text { ABD- } \\
\text { Florida }\end{array}$} & \multirow{2}{*}{ w.w. } & \multirow{2}{*}{ ppm } & \multicolumn{9}{|c|}{$0.18-4.0$} & \multirow{2}{*}{ Adams \& McMichael, 2007} \\
\hline Scomberomorus maculatus & & & & & & & & & $0.04-3.2$ & & & & \\
\hline Scomberomorus commerson & \multirow{3}{*}{ Cambodia } & \multirow{8}{*}{ d.w. } & \multirow{8}{*}{$\mu \mathrm{g} \mathrm{g^{-1 }}$} & 17.5 & & 1.33 & 0.002 & 0.003 & 0.07 & & 0.37 & 0.448 & \multirow{8}{*}{ Agusa et al., 2007} \\
\hline Rastrelliger brachysoma & & & & 17.4 & & 1.80 & 0.031 & 0.098 & $<0.05$ & & 0.40 & 0.367 & \\
\hline Auxis thazard thazard & & & & 18.1 & & 1.33 & 0.016 & 0.004 & 0.23 & & 0.40 & 0.342 & \\
\hline Sconberomorus sp & \multirow{2}{*}{ Indonesia } & & & 15.3 & & 2.22 & 0.007 & 0.031 & 0.65 & & 0.31 & 0.639 & \\
\hline Rastrelliger kanagurta & & & & 15.0 & & 1.09 & 0.017 & 0.013 & 0.12 & & 0.33 & 0.736 & \\
\hline Rastrelliger brachysoma & Malaysia & & & 23.2 & & 1.94 & 0.029 & 0.029 & $<0.05$ & & 0.57 & 0.334 & \\
\hline Rastrelliger brachysoma & $\begin{array}{l}\text { Thailand- } \\
\text { Song Khla }\end{array}$ & & & 50.7 & & 2.69 & 0.053 & 0.093 & 0.08 & & 0.38 & 0.419 & \\
\hline Rastrelliger brachysoma & $\begin{array}{l}\text { Thailand - } \\
\text { Ranong }\end{array}$ & & & 21.1 & & 1.65 & 0.015 & 0.069 & $<0.05$ & & 0.52 & 0.217 & \\
\hline Scomberomorus commerson & $\begin{array}{l}\text { Egypt- } \\
\text { El-Mex Bay } \\
\end{array}$ & d.w. & $\mathrm{mg} \mathrm{kg}^{-1}$ & $\begin{array}{l}17.7-31.0 \\
22.4 \pm 7.5\end{array}$ & & $<0.003$ & $\begin{array}{c}0.98-2.52 \\
1.9 \pm 0.8\end{array}$ & $\begin{array}{c}<0.0006- \\
0.19 \\
0.14 \pm 0.1 \\
\end{array}$ & & & $\begin{array}{l}5.9-6.9 \\
6.4 \pm 0.5\end{array}$ & & Ahmed \& Abdallah, 2008 \\
\hline Thunnus albacares & $\begin{array}{l}\text { Pakistan- } \\
\text { Karachi }\end{array}$ & d.w. & $\mu \mathrm{g} \mathrm{g}^{-1}$ & $12.64-44.50$ & $13.36-2.78$ & $1.68-9.82$ & $0.21-0.80$ & $0.02-0.75$ & & & & $2.10-9.98$ & Ahmed et al., 2012 \\
\hline Rastrelliger kanagurta & $\begin{array}{l}\begin{array}{l}\text { Pakistan- } \\
\text { Karachi }\end{array} \\
\end{array}$ & d.w. & $\mu \mathrm{g} \mathrm{g}^{-1}$ & $\begin{array}{l}9.41 \pm 3.14 \\
2.96 \pm 1.22 \\
\end{array}$ & $\begin{array}{l}18.92 \pm 13.12 \\
56.17 \pm 24.23 \\
\end{array}$ & $\begin{array}{l}8.21 \pm 3.37 \\
2.03 \pm 2.23 \\
\end{array}$ & & & & & & $\begin{array}{l}6.15 \pm 4.44 \\
1.42 \pm 1.20\end{array}$ & Ahmed et al., 2014a \\
\hline Euthynnus affinis & $\begin{array}{l}\text { Pakistan- } \\
\text { Karachi } \\
\end{array}$ & d.w. & $\mu \mathrm{g} \mathrm{g}^{-1}$ & $\begin{array}{l}16.33 \pm 2.26 \\
6.56 \pm 1.06 \\
\end{array}$ & & $\begin{array}{l}6.63 \pm 1.65 \\
2.36 \pm 1.78 \\
\end{array}$ & $\begin{array}{l}0.54 \pm 0.15 \\
0.06 \pm 0.05\end{array}$ & $\begin{array}{l}0.50 \pm 0.17 \\
0.14 \pm 0.12 \\
\end{array}$ & & & & & Ahmed et al., 2014b \\
\hline Scomberomorus commerson & $\begin{array}{l}\text { Pakistan- } \\
\text { Karachi }\end{array}$ & d.w. & $\mu \mathrm{g} \mathrm{g}^{-1}$ & $3.17-9.43$ & 23.71-44.40 & $2.78-6.83$ & $0.14-0.57$ & $0.19-0.68$ & & & $0.14-0.51$ & $1.30-2.20$ & Ahmed et al, 2015 \\
\hline Rastrelliger kanagurta & $\begin{array}{l}\text { Pakistan- } \\
\text { Karachi }\end{array}$ & d.w. & $\mathrm{mg} \mathrm{kg}^{-1}$ & & & & & & $\begin{array}{c}0.01-0.09 \\
0.042 \pm 0.023\end{array}$ & & & & Ahmed \& Bat, 2015 \\
\hline Rastrelliger kanagurta & $\begin{array}{l}\text { Pakistan- } \\
\text { Karachi }\end{array}$ & d.w. & $\mu \mathrm{g} \mathrm{g}^{-1}$ & & & & $0.32 \pm 0.26$ & $0.31 \pm 0.29$ & & & $0.37 \pm 0.26$ & & Ahmed et al., 2016 \\
\hline Katsuwonus pelamis & $\begin{array}{l}\text { Pakistan- } \\
\text { Karachi }\end{array}$ & d.w. & $\mu \mathrm{g} \mathrm{g}^{-1}$ & $\begin{array}{l}2 \pm 1 \\
7 \pm 2 \\
\end{array}$ & $\begin{array}{c}16 \pm 6 \\
46 \pm 17\end{array}$ & $\begin{array}{l}3 \pm 1 \\
7 \pm 2 \\
\end{array}$ & & & & & & $\begin{array}{l} \pm 1 \\
6 \pm 2 \\
6 \pm 2\end{array}$ & Ahmed et al., 2017 \\
\hline \multirow{2}{*}{ Scomberomorus commerson } & $\begin{array}{l}\text { Red Sea of } \\
\text { Yemen }\end{array}$ & \multirow{6}{*}{ d.w. } & \multirow{6}{*}{ ppm } & $2.23 \pm 0.10$ & & $0.32 \pm 0.09$ & $0.23 \pm 0.04$ & $0.09 \pm 0.01$ & & & & & \multirow{6}{*}{ Al-Shwafi, 2002} \\
\hline & $\begin{array}{l}\text { Gulf of } \\
\text { Aden }\end{array}$ & & & $2.10 \pm 0.09$ & & $0.30 \pm 0.08$ & $0.27 \pm 0.05$ & $1.07 \pm 0.02$ & & & & & \\
\hline \multirow{2}{*}{ Rastrelliger kanagurta } & $\begin{array}{l}\text { Red Sea of } \\
\text { Yemen }\end{array}$ & & & $0.75 \pm 0.08$ & & $0.11 \pm 0.03$ & $0.03 \pm 0.01$ & $0.03 \pm 0.02$ & & & & & \\
\hline & $\begin{array}{l}\text { Gulf of } \\
\text { Aden }\end{array}$ & & & $0.55 \pm 0.05$ & & $0.09 \pm 0.04$ & $0.05 \pm 0.03$ & $0.07 \pm 0.01$ & & & & & \\
\hline \multirow{2}{*}{ Thunnus albacares } & $\begin{array}{l}\text { Red Sea of } \\
\text { Yemen }\end{array}$ & & & $3.17 \pm 0.07$ & & $0.35 \pm 0.07$ & $0.25 \pm 0.09$ & $0.11 \pm 0.02$ & & & & & \\
\hline & $\begin{array}{l}\text { Gulf of } \\
\text { Aden }\end{array}$ & & & $3.00 \pm 0.05$ & & $0.32 \pm 0.08$ & $0.31 \pm 0.04$ & $0.27 \pm 0.03$ & & & & & \\
\hline Rastrelliger kanagurta & \multirow{2}{*}{$\begin{array}{l}\text { Straits of } \\
\text { Malacca }\end{array}$} & \multirow[b]{2}{*}{ w.w. } & \multirow[b]{2}{*}{$\mu \mathrm{g} \mathrm{g}^{-1}$} & & & & $\begin{array}{l}0.03 \pm 0.01 \\
0.15 \pm 0.02\end{array}$ & $\begin{array}{l}0.7 \pm 0.07 \\
1.05 \pm 0.00\end{array}$ & $1.1-1.0$ & $\begin{array}{l}0.25 \pm 0.01 \\
0.24 \pm 0.03\end{array}$ & & & \multirow{2}{*}{ Alina et al., 2012} \\
\hline Scomberomorus guttatus & & & & & & & $\begin{array}{l}.15 \pm 0.02 \\
0.04 \pm 0.01 \\
0.01 \pm 0.00\end{array}$ & $\begin{array}{l}1.05 \pm 0.00 \\
1.4 \pm 0.05 \\
0.89 \pm 0.00\end{array}$ & $2.2-2.0$ & $\begin{array}{l}0.24 \pm 0.03 \\
1.10 \pm 0.03 \\
0.64 \pm 0.03\end{array}$ & & & \\
\hline Tuna & Saudi Arabia & w.w. & $\mu \mathrm{g} \mathrm{g}^{-1}$ & $3.80-17.70$ & $1.11-5.32$ & $0.13-1.87$ & $0.03-0.51$ & $0.07-0.64$ & & & $0.07-0.33$ & & Ashraf et al., 2006 \\
\hline Scomber japonicus & Korea & d.w. & $\mathrm{mg} \mathrm{kg}^{-1}$ & & & & $\begin{array}{l}0.01 \pm 0.00 \\
0.02 \pm 0.01\end{array}$ & & $\begin{array}{l}0.04 \pm 0.01 \\
0.08 \pm 0.03\end{array}$ & & & & Bae \& Lim, 2012 \\
\hline Sarda sarda & Turkey & d.w. & $\mu \mathrm{g} \mathrm{g} \mathrm{g}^{-1}$ & $11.20 \pm 1.44$ & $9.52 \pm 0.81$ & $1.28 \pm 0.14$ & $0.76 \pm 0.05$ & $0.90 \pm 0.07$ & & & & $1.06 \pm 0.27$ & Tüzen, 2003 \\
\hline
\end{tabular}




\begin{tabular}{|c|c|c|c|c|c|c|c|c|c|c|c|c|c|}
\hline Sarda sarda & Turkey & d.w. & $\mu \mathrm{g} \mathrm{g}^{-1}$ & $48.7 \pm 3.7$ & $73.5 \pm 6.3$ & $0.84 \pm 0.05$ & $0.76 \pm 0.05$ & $0.90 \pm 0.07$ & & $1.06 \pm 0.10$ & & $2.68 \pm 0.22$ & Uluozlu et al., 2007 \\
\hline Sarda sarda & Turkey & w.w. & $\mu \mathrm{g} \mathrm{g}^{-1}$ & 12.66 & 12.18 & 0.659 & 0.537 & 0.031 & & & & 1.72 & Bat et al., 2006 \\
\hline Sarda sarda & Turkey & w.w. & $\mu \mathrm{g} \mathrm{g}^{-1}$ & $64.9 \pm 5.2$ & $68.5 \pm 5.4$ & $1.43 \pm 0.12$ & $0.61 \pm 0.04$ & $0.13 \pm 0.01$ & $\begin{array}{l}25 \pm 2 \\
\mu \mathrm{g} \mathrm{kg}\end{array}$ & $0.14 \pm 0.01$ & $0.68 \pm 0.05$ & $4.72 \pm 0.24$ & \multirow{2}{*}{ Tuzen, 2009} \\
\hline Scomber scombrus & Turkey & w.w. & $\mu \mathrm{g} \mathrm{g}^{-1}$ & $88.2 \pm 4.6$ & $87.3 \pm 5.2$ & $1.10 \pm 0.10$ & $0.45 \pm 0.03$ & $0.15 \pm 0.01$ & $\begin{array}{l}60 \pm 3 \\
\mu \mathrm{g} \mathrm{kg}\end{array}$ & $0.32 \pm 0.02$ & $0.73 \pm 0.05$ & $5.15 \pm 0.34$ & \\
\hline Sarda sarda & Turkey & d.w. & $\mu \mathrm{g} \mathrm{g}^{-1}$ & $21.0 \pm 2.1$ & $25.5 \pm 2.3$ & $1.9 \pm 0.2$ & $0.28 \pm 0.03$ & $0.35 \pm 0.04$ & & & $0.64 \pm 0.06$ & $2.0 \pm 0.2$ & Mendil et al., 2010 \\
\hline Sarda sarda & Turkey & d.w. & $\mu \mathrm{g} \mathrm{g}^{-1}$ & $19.55 \pm 1.20$ & $25.96 \pm 2.73$ & $1.74 \pm 0.18$ & $0.90 \pm 0.11$ & $0.025 \pm 0.005$ & ND & & & $3.53 \pm 0.48$ & Nisbet et al., 2010 \\
\hline Thunnus albacares & Australia & & $\mathrm{ppm}$ & $1.8-24.0$ & & & $0.1-0.8$ & $0.02-0.08$ & $0.11-.066$ & $0.2-2.2$ & & & Bebbington et al., 1977 \\
\hline Rastrelliger kanagurta & India & d.w. & $\mu \mathrm{g} \mathrm{g}^{-1}$ & $9.97-29.82$ & $10.4-75.3$ & $0.5-4.0$ & & $0.01-1.10$ & $0.27-9.50$ & $0.07-0.97$ & & $0.5-1.5$ & Bhupander et al, 2012 \\
\hline Sarda orientalis & \multirow{3}{*}{ India } & \multirow{3}{*}{ d.w. } & \multirow{3}{*}{$\mu \mathrm{g} \mathrm{g}^{-1}$} & & & & & & & & & & \multirow{3}{*}{ Biswas et al,, 2011} \\
\hline Scomberomorus commerson & & & & & 17.7 & & & & & & & 0.5 & \\
\hline Rastrelliger kanagurta & & & & & & & & & & & 0.24 & 1.7 & \\
\hline Scomber scombrus & $\begin{array}{l}\text { Northeast } \\
\text { Atlantic }\end{array}$ & w.w. & $\mathrm{mg} \mathrm{kg}^{-1}$ & $3.3-5.2$ & & $0.70-0.97$ & & & & & & & Celik \& Oehlenschlager 2004 \\
\hline Scomberomorus guttatus & \multirow{2}{*}{ India } & \multirow{2}{*}{ w.w. } & \multirow{2}{*}{$\begin{array}{l}\mathrm{mg} / 100 \mathrm{~g} \\
\mu \mathrm{g} / 100 \mathrm{~g}\end{array}$} & $1.5 \mathrm{mg} / 100 \mathrm{~g}$ & $1.1 \mathrm{mg} / 100 \mathrm{~g}$ & $22.3 \mu \mathrm{g} / 100 \mathrm{~g}$ & & & & & $\begin{array}{c}33.4 \\
\mu \mathrm{g} / 100 \mathrm{~g}\end{array}$ & $26.0 \mu \mathrm{g} / 100 \mathrm{~g}$ & \multirow{2}{*}{ Chandrashekar \& Deosthale, 1993} \\
\hline Rastrelliger kanagurta & & & & $2.3 \mathrm{mg} / 100 \mathrm{~g}$ & $1.3 \mathrm{mg} / 100 \mathrm{~g}$ & $84.9 \mu \mathrm{g} / 100 \mathrm{~g}$ & & & & & $\begin{array}{c}31.8 \\
\mu \mathrm{g} / 100 \mathrm{~g}\end{array}$ & $42.4 \mu \mathrm{g} / 100 \mathrm{~g}$ & \\
\hline Rastrelliger kanagurta & Mumbai & - & $\mu \mathrm{g} \mathrm{g}^{-1}$ & & & $0.07-0.60$ & $0.01-0.24$ & $0.007-0.019$ & $0.029-1.78$ & $0.01-0.11$ & & & Deshpande et al., 2009 \\
\hline Scomberomorus guttatus & Iran & w.w. & $\mathrm{mg} \mathrm{kg}^{-1}$ & & & $1.03-3.376$ & $0.085-1.515$ & $0.009-0.271$ & & & & & Dobaradaran et al., 2010 \\
\hline Canned Tuna Fish & Iran & $\begin{array}{c}\text { processed } \\
\text { product }\end{array}$ & $\mu \mathrm{g} \mathrm{g}^{-1}$ & & & & $\begin{array}{c}0.0162- \\
0.0726 \\
\end{array}$ & $\begin{array}{c}0.0046- \\
0.0720 \\
\end{array}$ & $0.0430-0.253$ & $\begin{array}{c}0.0369- \\
0.0261 \\
\end{array}$ & & & Emami Khansari et al., 2005 \\
\hline Rastrelliger brachysoma & \multirow{2}{*}{ Malaysia } & \multirow{2}{*}{ w.w. } & \multirow{2}{*}{$\mu \mathrm{g} \mathrm{g}^{-1}$} & & & & & & $\begin{array}{l}0.229 \pm 0.011 \\
0.778 \pm 0.074\end{array}$ & & & & \multirow{2}{*}{ Hajeb et al., 2010} \\
\hline Thunnus tonggol & & & & & & & & & $\begin{array}{l}0.225 \pm 0.045 \\
0.914 \pm 0.066 \\
\end{array}$ & & & & \\
\hline Canned tuna fish & \multirow{2}{*}{$\begin{array}{l}\text { Georgia and } \\
\text { Alabama }\end{array}$} & \multirow{2}{*}{$\begin{array}{c}\text { processed } \\
\text { product } \\
\text { d.w. }\end{array}$} & \multirow{2}{*}{$\mu \mathrm{g} \mathrm{kg}^{-1}$} & $0.14-9.87$ & $0.01-88.4$ & $0.01-0.51$ & $0.0-31.1$ & $0.0-53.9$ & $53.0-739.6$ & $0.0-1.72$ & $0.0-67.6$ & $0.08-0.63$ & \multirow{2}{*}{ Ikem \& Egiebor, 2005} \\
\hline Canned Mackerel fish & & & & $3.01-10.99$ & $5.16-34.1$ & $0.42-1.28$ & $0.0-0.0$ & $0.0-0.0$ & $19.5-48.9$ & $0.0-0.15$ & $11.1-298.6$ & $0.03-1.27$ & \\
\hline Scomberomorus commersoni & \multirow{2}{*}{ Malaysia } & \multirow{2}{*}{ d.w. } & \multirow{2}{*}{ ppm } & $38.81 \pm 5.98$ & & $11.74 \pm 1.88$ & $1.00 \pm 0.25$ & $0.30 \pm 0.06$ & ND & & & $20.13 \pm 3.08$ & \multirow{2}{*}{ Irwandi \& Farida, 2009} \\
\hline Rastrelliger kanagurta & & & & $34.33 \pm 5.90$ & & $13.95 \pm 2.70$ & $0.90 \pm 0.10$ & $0.30 \pm 0.09$ & $0.02 \pm 0.00$ & & & $16.8 \pm 1.80$ & \\
\hline Thuпnus thynnus & \multirow{2}{*}{ Korea } & \multirow{2}{*}{ w.w. } & & & & & & & $\begin{array}{c}0.18 \pm 0.01 \\
0.24 \pm 0.007\end{array}$ & $\begin{array}{l}1.56 \pm 0.05 \\
1.80 \pm 0.03\end{array}$ & & & \\
\hline Scomberomorus niphonius & & & & & & & & & $\begin{array}{l}0.04 \pm 0.002 \\
0.04 \pm 0.003\end{array}$ & $\begin{array}{l}1.47 \pm 0.14 \\
2.71 \pm 0.22\end{array}$ & & & \\
\hline Thunnus tonggol (canned) & USA & & $\mathrm{mg} \mathrm{kg}^{-1}$ & & & & & & $0.22 \pm 0.009$ & $1.03 \pm 0.04$ & & & Islam et al., 2010 \\
\hline Thunnus thynnus (canned) & Thailand & product & & & & & & & $0.09 \pm 0.01$ & $1.41 \pm 0.08$ & & & \\
\hline Thunnus thynnus (canned) & Korea & & & & & & & & $0.07 \pm 0.006$ & $1.06 \pm 0.09$ & & & \\
\hline Thuпnus thynnus & D. & & 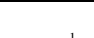 & $1.271 \pm 0.465$ & $2.180 \pm 0.411$ & $0.209 \pm 0.01$ & $0.078 \pm 0.013$ & $0.023 \pm 0.006$ & $0.078 \pm 0.009$ & $0.810 \pm 0.016$ & $0.033 \pm 0.006$ & $0.082 \pm 0.029$ & 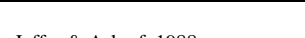 \\
\hline Thunnus tonggel & Pakistan & w.w. & $\mu \mathrm{g} \mathrm{g}^{2}$ & $3.490 \pm 0.600$ & $0.425 \pm 0.084$ & $0.164 \pm 0.037$ & $0.086 \pm 0.023$ & $0.027 \pm 0.007$ & $0.032 \pm 0.005$ & $0.674 \pm 0.213$ & $0.075 \pm 0.019$ & $0.052 \pm 0.016$ & Jaftar \& Ashrat, 1988 \\
\hline Rastrelliger kanagurta & India & d.w. & $\mu \mathrm{g} \mathrm{g}^{-1}$ & $6.1-$ & $0.0-2.71$ & $0.0-0.89$ & $0.0-0.0$ & $0.0-1.4$ & & & & $0.0-0.0$ & Kaladharan et al., 2006 \\
\hline Rastrelliger kanagurta & & & & & & & & 0.031 & & 1.580 & & & \\
\hline Scomberomorus commerson & Thailand & w.w. & $\mu \mathrm{g} \mathrm{g}^{-1}$ & & & & & 0.009 & & 1.476 & & & Kerdthep et al., 2009 \\
\hline Thunnus tonggol & & & & & & & & 0.021 & & 0.957 & & & \\
\hline Scomberomorus commerson & Egypt & w.w. & $\mu \mathrm{g} \mathrm{g}^{-1}$ & 5.24 & 8.11 & 1.46 & 0.64 & 0.13 & & & 0.15 & 0.83 & Khaled, 2004 \\
\hline Scomberomorous commerson & & & & & $52.318 \pm 7.987$ & $2.431 \pm 0.531$ & $1.314 \pm 0.142$ & $0.315 \pm 0.074$ & $0.243 \pm 0.054$ & & & & \\
\hline Rastrelliger kanagurta & Iran & - & $\mathrm{mg} \mathrm{kg}^{-1}$ & & $5.791 \pm 0.987$ & $2.321 \pm 0.137$ & $0.392 \pm 0.131$ & $0.112 \pm 0.007$ & $0.089 \pm 0.031$ & & & & Khoshnood et al., 2012 \\
\hline Scomberomorus guttatus & & & & & $47.932 \pm 5.320$ & $2.983 \pm 0.123$ & $0.963 \pm 0.143$ & $0.021 \pm 0.012$ & $0.184 \pm 0.123$ & & & & \\
\hline
\end{tabular}




\begin{tabular}{|c|c|c|c|c|c|c|c|c|c|c|c|c|c|}
\hline Thannus tonggol & & & & & $15.392 \pm 1.543$ & $1.874 \pm 0.054$ & $1.215 \pm 0.210$ & $0.212 \pm 0.054$ & $0.102 \pm 0.012$ & & & & \\
\hline Tunnus albacares & \multirow{2}{*}{$\begin{array}{l}\text { Western } \\
\text { Indian } \\
\text { Ocean }\end{array}$} & \multirow{2}{*}{ d.w. } & \multirow{2}{*}{$\mu \mathrm{g} \mathrm{g^{-1 }}$} & $\begin{array}{l}64.1 \pm 47.3 \\
160 \pm 135\end{array}$ & $\begin{array}{c}39.6 \pm 16.8 \\
50.6 \pm 34\end{array}$ & $\begin{array}{l}0.97 \pm 0.23 \\
1.99 \pm 1.47\end{array}$ & $\begin{array}{l}0.09 \pm 0.14 \\
0.02 \pm 0.07\end{array}$ & $\begin{array}{l}0.25 \pm 0.21 \\
0.23 \pm 0.20\end{array}$ & $\begin{array}{l}0.56 \pm 0.38 \\
1.15 \pm 2.30\end{array}$ & & & $\begin{array}{l}0.27 \pm 0.11 \\
0.30 \pm 0.12\end{array}$ & \multirow{2}{*}{ Kojadinovic et al., 2007} \\
\hline Katsuwonus pelamis & & & & $125 \pm 94$ & $70.2 \pm 34.4$ & $1.02 \pm 0.89$ & $0.07 \pm 0.08$ & $0.61 \pm 0.37$ & $0.67 \pm 0.26$ & & & $0.36 \pm 0.16$ & \\
\hline Rastrelliger kanagurta & India & w.w. & $\mu \mathrm{g} \mathrm{g}^{-1}$ & $6.66 \pm 0.75$ & & $1.16 \pm 0.16$ & $0.006 \pm 0.002$ & $0.66 \pm 0.08$ & & & & & Krishna Kumar et al., 1990 \\
\hline Canned Tuna Fish & Iran & $\begin{array}{c}\text { processed } \\
\text { product }\end{array}$ & $\mu \mathrm{g} \mathrm{g}^{-1}$ & $0.36 \pm 0.77$ & & & $0.11 \pm 0.2115$ & $\begin{array}{c}0.019 \pm 0.351 \\
9\end{array}$ & & & & & Malakootian et al., 2011 \\
\hline Canned Tuna Fish & Turkey & $\begin{array}{c}\text { processed } \\
\text { product }\end{array}$ & $\mathrm{mg} \mathrm{kg}^{-1}$ & $3.68-30.1$ & ND-80.7 & $0.08-1.77$ & ND-4.13 & $\mathrm{ND}-0.09$ & $\mathrm{ND}-1.14$ & & & & Mol, 2011 \\
\hline Rastrelliger kanagurta & India & d.w. & $\mu \mathrm{g} \mathrm{g}^{-1}$ & & & & & $0.01-2.07$ & $0.27-1.60$ & $0.07-1.63$ & & & Mukherjee et al., 2011 \\
\hline Rastrelliger kanagurta & India & d.w. & $\mu \mathrm{g} \mathrm{g}^{-1}$ & 35.93 & & & 7.57 & $<0.001$ & & & & 6.69 & Nair et al., 2006 \\
\hline Rastrellinger kanagurta & Malaysia & w.w. & $\mathrm{mg} \mathrm{kg}^{-1}$ & & & & $\begin{array}{l}1.506 \pm 0.095 \\
1.594 \pm 0.053 \\
\end{array}$ & $\begin{array}{l}0.863 \pm 0.042 \\
0.982 \pm 0.055 \\
\end{array}$ & & & & & Nor Hasyimah et al., 2011 \\
\hline Rastrelliger kanagurta & India & d.w. & $\mathrm{Ppm}$ & 24.40 & 500.75 & 2.06 & 0.34 & 3.11 & & & & & Rejomon et al., 2010 \\
\hline Scomberomorus commerson & \multirow{2}{*}{ Iran } & \multirow{2}{*}{ w.w. } & \multirow{2}{*}{$\mu \mathrm{g} \mathrm{g^{-1 }}$} & $9.677 \pm 2.226$ & & $4.552 \pm 0.876$ & $0.223 \pm 0.135$ & $0.078 \pm 0.048$ & & & & & \multirow{2}{*}{ Saei-Dehkordi \& Fallah, 2011} \\
\hline Thunus tonggol & & & & $11.209 \pm 3.250$ & & $3.907 \pm 1.191$ & $0.235 \pm 0.135$ & $0.106 \pm 0.047$ & & & & & \\
\hline Scomberomorus guttatus & India & w.w. & $\mathrm{mg} \mathrm{kg}^{-1}$ & $\begin{array}{l}2.08 \pm 0.05 \\
39.2 \pm 0.08\end{array}$ & & $\begin{array}{l}0.48 \pm 0.04 \\
3.16 \pm 0.06\end{array}$ & $\begin{array}{c}\text { ND- } \\
1.32 \pm 0.01 \\
\end{array}$ & $\begin{array}{c}\text { ND- } \\
0.08 \pm 0.01 \\
\end{array}$ & $\begin{array}{c}\text { ND- } \\
0.28 \pm 0.21\end{array}$ & $\begin{array}{c}\text { ND- } \\
1.66 \pm 0.03\end{array}$ & $\begin{array}{l}0.24 \pm 0.05 \\
1.87 \pm 0.01\end{array}$ & $\begin{array}{l}0.14+0.11 \\
0.72 \pm 0.02\end{array}$ & Sivaperumal et al., 2007 \\
\hline Scomberomorus commerson & - & - & $\mu \mathrm{g} \mathrm{g}^{-1}$ & $\begin{array}{c}\text { (Zn II) } \\
0.005 \\
\end{array}$ & & $\begin{array}{c}\text { (Cu II) } \\
0.016 \\
\end{array}$ & & $\begin{array}{c}\text { (Cd II) } \\
0.007 \\
\end{array}$ & & & & & Sobhanardakani et al., 2011 \\
\hline Thunnus thynnus & Adriatic Sea & w.w. & $\mu \mathrm{g} \mathrm{g}^{-1}$ & & & & & & 0.49 to 1.809 & & & & Srebocan et al., 2007 \\
\hline Scomber scombrus(canned) & Turkey & $\begin{array}{c}\text { processed } \\
\text { product } \\
\text { d.w. }\end{array}$ & $\mathrm{mg} \mathrm{kg}^{-1}$ & & & & $0.05-0.181$ & $0.07-0.021$ & & & & & Sireli et al., 2006 \\
\hline Rastrelliger kanagurta & Pakistan & w.w. & $\mu \mathrm{g} \mathrm{g}^{-1}$ & $19.83 \pm 2.00$ & $1791 \pm 137$ & $1.56 \pm 0.22$ & $0.14 \pm 0.02$ & $0.36 \pm 0.10$ & $0.16 \pm 0.09$ & & $8.51 \pm 0.59$ & $7.68 \pm 1.15$ & Tariq et al., 1993 \\
\hline Canned Tuna Fish & \multirow{2}{*}{ Turkey } & \multirow{2}{*}{$\begin{array}{c}\text { processed } \\
\text { product } \\
\text { w.w }\end{array}$} & \multirow{2}{*}{$\mu \mathrm{g} \mathrm{g}^{-1}$} & $17.8 \pm 1.2$ & $14.9 \pm 1.1$ & $2.50 \pm 0.12$ & $0.10 \pm 0.01$ & $0.08 \pm 0.006$ & & & $1.08 \pm 0.10$ & $0.90 \pm 0.08$ & \multirow{2}{*}{ Tüzen \& Soylak, 2007} \\
\hline Canned Black Sea bonito & & & & $8.61 \pm 0.70$ & $10.2 \pm 0.9$ & $1.28 \pm 0.10$ & $0.25 \pm 0.02$ & $0.06 \pm 0.005$ & & & $1.46 \pm 0.13$ & $1.52 \pm 0.13$ & \\
\hline Scomber japonicus & Turkey & w.w. & $\mathrm{mg} \mathrm{kg}^{-1}$ & $\begin{array}{l}3.51 \pm 0.35 \\
25.2 \pm 8.87 \\
\end{array}$ & $\begin{array}{r}14.8 \pm 4.42 \\
68.1 \pm 20.5 \\
\end{array}$ & $\begin{array}{l}0.51 \pm 0.11 \\
6.22 \pm 1.49 \\
\end{array}$ & $\begin{array}{l}0.21 \pm 0.03 \\
0.54 \pm 0.17 \\
\end{array}$ & $\begin{array}{c}<0.01 \pm 0.00 \\
0.08 \pm 0.04 \\
\end{array}$ & & & $\begin{array}{l}0.15 \pm 0.04 \\
0.48 \pm 0.11 \\
\end{array}$ & $\begin{array}{l}0.18 \pm 0.06 \\
1.58 \pm 0.69 \\
\end{array}$ & Turkmen et al., 2009 \\
\hline Rastrelliger kanagurta & India & d.w. & $\mu \mathrm{g} \mathrm{g}^{-1}$ & $20.1 \pm 0.13$ & & $0.42 \pm 0.09$ & & $0.35 \pm 0.06$ & & & $0.66 \pm 0.08$ & & Vijayakumar et al., 2011 \\
\hline Thunnus tonggol & $\begin{array}{l}\text { Pakistan- } \\
\text { Karachi } \\
\end{array}$ & & $\mu \mathrm{g} \mathrm{g}^{-1}$ & $\begin{array}{c}0.43 \pm 0.28 \\
17.47 \pm 7.56 \\
\end{array}$ & $\begin{array}{c}0.98 \pm 0.49 \\
1.81 \pm 0.712 \\
\end{array}$ & $\begin{array}{r}8.27 \pm 5.79 \\
10.29 \pm 3.33 \\
\end{array}$ & & & & & & $\begin{array}{c}0.05 \pm 0.02 \\
12.57 \pm 7.86 \\
\end{array}$ & Yousuf \& Ahmed, 2010 \\
\hline Rastrelliger kanagurta & Pakistan & - & $\mu \mathrm{g} \mathrm{g}^{-1}$ & 4.53-12.71 & $5.89-12.74$ & $1.94-9.81$ & & & & & & $0.17-3.67$ & Yousuf \& Ahmed, 2011 \\
\hline Canned Tuna Fish & Iran & $\begin{array}{c}\text { processed } \\
\text { product } \\
\text { d.w. }\end{array}$ & $\mu \mathrm{g} \mathrm{g}^{-1}$ & $0.124-27.001$ & $0.009-14.207$ & $0.017-8.001$ & $0.007-0.510$ & $0.002-0.070$ & & & & & Zarei et al., 2010 \\
\hline
\end{tabular}


Ahmed et al. (2012) studied metal concentrations in Thunnus albacares from Karachi Fish Harbour during February to November 2011. The highest mean concentration of $\mathrm{Fe} 46.93+13.54 \mu \mathrm{g} / \mathrm{g}$ dry wt. and $\mathrm{Mn}$ $5.40+3.06 \mu \mathrm{g} / \mathrm{g}$ dry wt. was determined in summer and spring season. The lowest mean of Fe $20.861+5.095 \mu / \mathrm{g}$ and $\mathrm{Mn} 4.80+1.41 \mu \mathrm{g} / \mathrm{g}$ dry wt. was recorded in spring and summer seasons also. The maximum level of $\mathrm{Zn}$ $29.95+11.41 \mu \mathrm{g} / \mathrm{g}$ dry wt., $\mathrm{Cu} 7.08+2.64 \mu \mathrm{g} / \mathrm{g}$ dry wt. and $\mathrm{Pb}$ $0.54+0.13 \mu \mathrm{g} / \mathrm{g}$ dry wt., was measured in winter season. The lowest mean of $\mathrm{Cd} 0.15+0.11 \mu \mathrm{g} / \mathrm{g}$ dry wt. was determined in spring season. The concentration of metals in fish muscles as follows: $\mathrm{Fe}>\mathrm{Zn}>\mathrm{Cu}>\mathrm{Mn}>\mathrm{Pb}>\mathrm{Cd}$.

Ahmed et al. (2014a) determined heavy metals Fe, $\mathrm{Mn}, \mathrm{Cu}$ and $\mathrm{Zn}$ concentration in fish samples of Rastrelliger kanagurta of various lengths $(\mathrm{cm})$ and weight $(\mathrm{g})$ were collected from the coast of Karachi fish Harbor during August, 2006 to December, 2011. Samples were analyzed as by using Atomic Absorption Spectroscopy. The highest $(24.0 \pm 1.75)$ and the lowest mean $(23.5 \pm 1.65)$ lengths of fish were measured in 2009-2010 and 2010-2011. The maximum $(132 \pm 22.76)$ and minimum $(126 \pm 18.65)$ weights were also measured in 2009-2010 and 2010-2011. The highest $(498.21 \pm 161.37 \mu \mathrm{g} / \mathrm{g})$ and lowest $(16.74 \pm 14.07 \mu \mathrm{g} / \mathrm{g})$ mean concentrations of $\mathrm{Fe}$ were recorded in liver and gonads of fish during 2007-2008. Maximum $(18.23 \pm 9.46 \mu \mathrm{g} / \mathrm{g})$ and minimum $(0.51 \pm 0.45 \mu \mathrm{g} / \mathrm{g})$ concentrations of $\mathrm{Mn}$ were determined in liver and gonads during 2006-2011.

Ahmed et al. (2014b) studied the fishery, biology, growth and stock structure of Euthynnus affinis is studied in detail. Hooks and lines, gillnets and purse seines are the major equipment used to exploit the fish. Fisheries are sustained mainly by 1-2 year old fishes $(34-50 \mathrm{~cm})$. Spawning was observed around the year with peaks during July-August and November January. The length-weight relationship is $0.0254 \mathrm{~L}^{2.889}$ with no significant difference between males and females. Age and growth are estimated using length based methods. The maximum sustainable yield estimated was higher than the average annual catch, indicating scope for further exploitation. Elevated levels of heavy metals in E. affinis may be a good indication of pollution of an aquatic ecosystem due to anthropogenic influences. A total of 278 fishes were collected from Karachi coast, Fish Harbor West Wharf, Karachi, for metal $(\mathrm{Cd}, \mathrm{Pb}, \mathrm{Zn}$ and $\mathrm{Cu})$ analysis in the organs of the fish. The metal levels in the sample fishes are in descending order of toxicity $\mathrm{Cd}>\mathrm{Pb}>\mathrm{Zn}>\mathrm{Cu}$. In the risk assessment, we assessed potential human health risks associated with consumption of fish, incorporating information gathered during a year-long, intercept-style creel angler survey and representative heavy metal concentrations in fish tissue. Fishing operations can cause ecological impacts of different types, e.g. by the catches, damage of the habitat, mortalities caused by lost or discarded gear, pollution, and generation of marine debris. Periodic reassessment of the tuna potential is required, with adequate inputs from exploratory surveys as well as commercial landings; this may prevent any unsustainable trends in the development of the tuna fishing industry in the Arabian Sea.

Ahmed et al. (2015) in the present study, Scomberomorus commerson was collected during the period 2006-2011 in order to provide information on the concentrations of eight heavy metals present in this marine species commonly consumed by the population and to have knowledge whether these levels may constitute a hazard to consumers. Liver showed high concentrations of metals in the tissues and organs. $\mathrm{Fe}$ is the most accumulated in all tissues and organs. The highest mean concentration of $\mathrm{Fe}$ $(608.93+113.22 \mu \mathrm{g} / \mathrm{g}), \quad \mathrm{Mn} \quad(9.79+4.22 \mu \mathrm{g} / \mathrm{g}), \quad \mathrm{Cu}$ $(38.57+16.62 \mu \mathrm{g} / \mathrm{g}), \mathrm{Zn}(53.25+26.50 \mu \mathrm{g} / \mathrm{g}), \mathrm{Ni}(3.22+1.13$ $\mu \mathrm{g} / \mathrm{g}), \mathrm{Pb}(1.20+0.64 \mu \mathrm{g} / \mathrm{g}), \mathrm{Cd}(2.03+0.91 \mu \mathrm{g} / \mathrm{g})$ and $\mathrm{Cr}$ $(1.93+0.87 \mu \mathrm{g} / \mathrm{g})$ was determined in liver of fish. The order of abundance of the metals in the fish samples based on concentrations in the muscle tissues analysed were as: $\mathrm{Fe}>\mathrm{Zn}>\mathrm{Cu}>\mathrm{Mn}>\mathrm{Ni}>\mathrm{Cd}>\mathrm{Pb} \geq \mathrm{Cr}$.

Ahmed and Bat (2015) were determined Hg levels in edible tissues of the Indian mackerel Rastrelliger kanagurta collected at Karachi Harbor of Pakistan between March 2013 and February 2014. Hg levels ranged from 0.01 to 0.09 with mean $\pm \mathrm{SD} 0.042 \pm 0.023 \mathrm{mg} / \mathrm{kg}$ dry wt. The $\mathrm{Hg}$ level in $R$. kanagurta is relatively low when compared to those studied in other parts of the world and is able to meet the legal standards by EU Commission Regulation and other international food standards. The findings obtained were also compared with established allowable weekly intake values. It is concluded that the $\mathrm{Hg}$ levels in the Indian mackerel from Karachi coasts did not exceed the permission limits $(0.5 \mathrm{mg} / \mathrm{kg})$. The results show that the Indian mackerel appears to be useful bio-indicator due to their accumulation of $\mathrm{Hg}$, however, continued sampling is required for further researches.

Ahmed et al. (2016) determined Nickel (Ni), Lead $(\mathrm{Pb})$, Cadmium $(\mathrm{Cd})$ and Chromium $(\mathrm{Cr})$ concentrations in muscle, liver, kidney, gills and gonads of Indian mackerel (Rastrelliger kanagurta) collected from Karachi fish Harbor, Karachi coast, Pakistan, during August 2006 and December 2011. Generally, the fish showed the highest level of $\mathrm{Ni}$ $\left(2.26+0.89 \mu \mathrm{g} \mathrm{g}^{-1}\right), \mathrm{Pb}\left(1.45+0.40 \mu \mathrm{g} \mathrm{g}^{-1}\right), \mathrm{Cd}(2.07+0.75 \mu \mathrm{g}$ $\left.\mathrm{g}^{-1}\right)$ and $\mathrm{Cr}\left(1.52+0.69 \mu \mathrm{g} \mathrm{g}^{-1}\right)$ in the liver. The studied metals were the most abundant in the liver than the other organs of the fish. The amount of metal accumulation in fish tissues was evaluated in terms of human health. It was seen that bioaccumulations in muscle tissues of the fish caught 
from Karachi coast of Pakistan did not exceed the limit values.

Ahmed et al. (2017) analyzed Fe, Mn, Cu and $\mathrm{Zn}$ levels in the edible dorsal tissues, livers, kidney, gills and gonads of skipjack tuna (Katsuwonus pelamis) from the Karachi coast between 2006 and 2011. The liver tissues had the highest concentrations of metals $\left(623 \pm 103 \mathrm{mg} \mathrm{kg}^{-1}\right.$ for $\mathrm{Fe}, 49 \pm 13 \mathrm{mg} \mathrm{kg}^{-1}$ for $\mathrm{Mn}, 67 \pm 17 \mathrm{mg} \mathrm{kg}^{-1}$ for $\mathrm{Cu}$ and $68 \pm 21$ $\mathrm{mg} \mathrm{kg}^{-1}$ for $\mathrm{Zn}$ ). The muscle maximum concentrations of $\mathrm{Fe}$, $\mathrm{Mn}, \mathrm{Cu}$, and $\mathrm{Zn}$ were $46 \pm 17,6 \pm 2,7 \pm 2$ and $7 \pm 2 \mathrm{mg} \mathrm{kg}^{-1}$, respectively. The results revealed that $\mathrm{Fe}$ concentrations were higher than those of other metals. The values obtained were compared with the international regulation maximal allowable standards in seafood. The current work attested that calculated diurnal and hebdomadal intakes of $\mathrm{Fe}, \mathrm{Mn}$, $\mathrm{Cu}$ and $\mathrm{Zn}$ levels by way of consumption of skipjack tuna were not in excess of the Permissible Tolerable Daily Intake (PTDI) and Provisional Tolerable Weekly Intake (PTWI) values established by FAO/WHO. In conclusion, $K$. pelamis appears to be useful bio-indicator due to their accumulation of the metals and continued sampling and pollution effects on food chain organisms comparatively are required for further investigations.

Al-Shwafi (2002) determined the metal $\mathrm{Zn}, \mathrm{Cu}, \mathrm{Pb}$, and $\mathrm{Cd}$ concentration in Crenidens crenidens, Scomberomorus commerson, Rastrelliger kanagurta and Thunnus albacares. The samples were collected from Red Sea of Yemen and the Gulf of Aden. The results show that, the variations within the muscles tissues of fish were mainly attributed to the geochemical nature of beach deposits rather than anthropogenic input. Thus, it was concluded that the investigated heavy metals do not present an environmental hazards for the present time. $\mathrm{Cd}, \mathrm{Pb}$ are harmful and causing the cancer diseases.

Alina et al. (2012) studied heavy metal concentration in 12 species of fish were collected from the Straits of Malacca Gymnura spp. (Long-tailed butterfly ray), Plotosus spp. (Gray eel catfish), Nemipterus janonicus (Japanese threadfin bream), Epinephulus sexfasciatus (Sixbar grouper), Psettodes erumei (Large-scale tongue sole), Lutianus argentimaculatus (Malabar red snapper), Rastrelliger kanagurta (Indian mackerel), Scomberomorus guttatus (Spanish mackerel), Pampus argenteus (Silver pompret), Megalapsis cordyla (torpedo scad), Eleutheronema tradactylum (Four-finger threadfin), Chirocentrus dorab (dorab wolf-herring), and three species of shellfish; Sepia officinalis (the common cuttlefish or European common cuttlefish), Anadara granosa (Cockles), Macrobrachium rosenbergi (Prawn). Heavy metals in samples were 1.0-3-6.5-3 $\mu \mathrm{g} / \mathrm{g}$ wet wt. for $\mathrm{Hg}, 0.5-2-47-2$ $\mu \mathrm{g} / \mathrm{g}$ wet wt. for $\mathrm{Cd}, 0.01-0.39 \mu \mathrm{g} / \mathrm{g}$ wet wt. for $\mathrm{Pb}$ and 0.14-6.57 $\mu \mathrm{g} / \mathrm{g}$ wet wt. for As.

The heavy metals $(\mathrm{Pb}, \mathrm{Cd}, \mathrm{Ni}, \mathrm{Cu}, \mathrm{Zn}, \mathrm{Cr}$ and $\mathrm{Fe}$ ) concentration in canned salmon, sardine and tuna fish. The metal contents, expressed in $\mu \mathrm{g} / \mathrm{g}$, wet wt., varied depending upon the specie studied. The levels of $\mathrm{Pb}$ ranged from 0.03 $1.20 \mu \mathrm{g} / \mathrm{g}$ with an average of $0.313 \mu \mathrm{g} / \mathrm{g}$ for salmon; 0.03 $0.51 \mu \mathrm{g} / \mathrm{g}$ with an average of $0.233 \mu \mathrm{g} / \mathrm{g}$ for tuna and 0.13 $1.97 \mu \mathrm{g} / \mathrm{g}$ with an average of $0.835 \mu \mathrm{g} / \mathrm{g}$ for sardines. The levels of $\mathrm{Cd}$ ranged from 0.02 to $0.38 \mu \mathrm{g} / \mathrm{g}$ with an average of $0.161 \mu \mathrm{g} / \mathrm{g}$ for salmon, from 0.07 to $0.64 \mu \mathrm{g} / \mathrm{g}$ with an average of $0.227 \mu \mathrm{g} / \mathrm{g}$ for tuna and from 0.010 to $0.690 \mu \mathrm{g} / \mathrm{g}$ with an average of $0.183 \mu \mathrm{g} / \mathrm{g}$ for sardines (Ashraf et al., 2006).

The toxic substances investigate the exposure of metals in eight fishes, yellowtail snapper (Ocyurus chrysurus), mutton or lane snapper (Lutjanus sp.), grouper/red hind/rock hind/ Coney (Epinephelus sp.), grunt (Haemulon sp.), parrotfish (Scaridae family), porgy (Sparidae family), goatfish (Mullidae family), or bonito (Scombridae family) (Agency for Toxic Substances and Disease Registry (ATSDR, 2002).

The effect of season on heavy metal contents in Chub Mackerel (Scomber japonicus).The sample were collected from Southern Sea of Korea. The average mercury and lead content varied between 0.04 and $0.08 \mathrm{mg} / \mathrm{kg}$ and between 0.01 and $0.02 \mathrm{mg} / \mathrm{kg}$, respectively. Seasonal variations were not detected in lead level, but mercury displayed maximal values in winter $(p<0.05)$ (Bae \& Lim 2012).

Very recently, Bat (2014) and Bat and Arıc1 (2018) reviewed heavy metal amounts and their effects on marine biota in the Black Sea and other sea coast of Turkey. Bat (2014) compiled heavy metal studies in 33 fish species between 1992 and 2012. The metal concentrations decrease in the order $\mathrm{Zn}>\mathrm{Fe}>\mathrm{Cu}>\mathrm{Mn}>\mathrm{Pb}>\mathrm{Ni}>\mathrm{Co}>\mathrm{Cd}$. It is indicated that there is no evidence for significant heavy metal pollution in the Black Sea. The current data is not enough to conclude future trends in metal contamination or to adequately protect ecosystems and public health. It is also pointed out that the methodologies of the studies were not inter-comparable and suggested that this situation is serious and warrants urgent action.

Bebbington et al. (1977) studied the heavy metal concentration $\mathrm{Cd}, \mathrm{Pb}, \mathrm{Cu}$, and $\mathrm{Zn}$ were measured in bream, snapper, mulloway, kingfish, Australian salmon, and yellowfin tuna fish. The concentration of $\mathrm{Cd}, \mathrm{Pb}, \mathrm{Cu}$, and $\mathrm{Zn}$ below the (NHMRC) standard for these elements in foods. The Hg in all species sampled occurred almost entirely as 
MeHg. Of the 95 fish analyzed for As and Se, 20 (21\%) had As concentrations. The results were equal to or greater than the NHMRC standard for Se (Bebbington et al., 1977).

The fish species collected from North East coast of India. The results obtained, $\mathrm{Cu}, \mathrm{Zn}, \mathrm{Mn}, \mathrm{Fe}, \mathrm{Cd}, \mathrm{Hg}$ and $\mathrm{As}$ in fishes was $0.5-28.2,3.0-99.1,0.5-12.0,10.4-249.7,0.01-$ $1.10,0.05-1.60$ and $0.02-2.37 \mu \mathrm{g} \mathrm{g}{ }^{-1}$ dry wt. respectively. Comparatively higher concentrations of heavy metals were accumulated in Trichiurus trichiurus, Pampus argentius, Harpadon nehereus and Arius sp. followed by Daysciaena albida, Formio niger, Hilsa ilisha and Rastrelliger kanagurta. The order of heavy metal concentration was $\mathrm{Fe}>\mathrm{Zn}>\mathrm{Cu}>\mathrm{Mn}>\mathrm{As}>\mathrm{Hg}>\mathrm{Cd}$ (Bhupander et al. 2012).

Heavy metal $\mathrm{Cu}, \mathrm{Mn}, \mathrm{Zn}, \mathrm{Fe}, \mathrm{Cr}$, and $\mathrm{Pb}$ concentration in nine commercially important and locally consumed fish species (Sarda orientalis, Scomberomorus commerson, Rastrelliger kanagurta, Sardinella longiceps, Paraplagusia bilineata, Cynoglossus lida, Cynoglossus macrostomus, Lepturacanthus savala and Siganus javus) collected from coastal waters of Kalpakkam, eastern part of India. Heavy metal concentrations $\left(\mu \mathrm{g} \mathrm{g}^{-1}\right)$ ranged as follows: $\mathrm{Cu}$ (0.8-6.5), $\mathrm{Zn}$ (14.3-27.9), $\mathrm{Mn}$ (0.5-8.8), $\mathrm{Fe}$ (17.6-117.0), $\mathrm{Cr}$ (0.24-1.78), and $\mathrm{Pb}(0.18-2.29)$ (Biswas et al., 2011).

Castro-González et al. (2008) stated that metals are utilized in a variety of ways in industries and agriculture in particular mercury, cadmium, lead and arsenic, which constitutes a significant potential threat to human health because they are associated with many adverse effects. The consumption of fish is recommended because it is a good source of omega-3 fatty acids, which have been associated with health benefits due to its cardio-protective effects. However, the content of heavy metals discovered in some fish makes it difficult to clearly establish the role of fish consumption on a healthy diet.

The concentration of lead and cadmium in 68 commercially used fish species from two European regions, the northeastern Atlantic (Tampen, north of the Shetland Islands, Faroe Islands and Copinsay) and the Mediterranean (Izmir Outer Bay, Homa Lagoon/Izmir and Mersin Bay), by means of differential pulse stripping anodic voltammetry. The maximum $\mathrm{Pb}$ concentration investigated to those from Tampen with $11.25 \mu \mathrm{g} / \mathrm{kg}$ and the average $\mathrm{Cd}$ concentration to fish from Copinsay with $2.23 \mu \mathrm{g} / \mathrm{kg}$. The Mediterranean fishes, highest average $\mathrm{Pb}$ and $\mathrm{Cd}$ concentrations belonged to those from Mersin Bay, with $185.39 \mu \mathrm{g} / \mathrm{kg}$ and 2.12 $\mu \mathrm{g} / \mathrm{kg}$, respectively (Celik et al., 2004).

Chandrashekar et al. (1993) analyzed mineral, trace element, amino acids, and proximate components in the edible muscle tissue of 17 marine fish (seer, hilsa, anchovy, black, Jew fish, mullet, mackerel, conger eel, pomfret white, trevally, pink perch, lesser sardine, threadfins, Bombay duck, giant perch, shark, and catfish) and 3 freshwater fish (murrel, rohu and catla). The heavy metal content per $100 \mathrm{~g}$ muscle was 4.7-51.4 mg Ca, 116-312 mg P, 29-54.3 mg Mg, 0.5-1.8 mg Fe, 1.1-3.2 mg Zn, 22.3-106.9 $\mu \mathrm{g} / \mathrm{g} \mathrm{Cu}, 9.7-79.7$ $\mu \mathrm{g} / \mathrm{g} \mathrm{Mn}$, and 15.8-69.3 $\mu \mathrm{g} / \mathrm{g} \mathrm{Cr}$.

In another heavy metal study, the sample Brama brama (Pomfret), Rachycentron canadus (Surmai/King Fish), Rastrelliger kanagurta (Mackerel), Eleutheronema tetradactylum (Ravas/Indian salmon) and Metapenaeus monoceros (Brown prawn) were collected from four different docks in the city. The heavy metals concentration in fish tissues were estimated using voltammeter and cold vapor atomic absorption spectrophotometer (Deshpande et al., 2009).

Dobaradaran et al. (2010) observed that heavy metal pollution of aquatic environment has become a great concern in recent years. Cadmium $(\mathrm{Cd})$, copper $(\mathrm{Cu})$, nickel $(\mathrm{Ni})$ and lead $(\mathrm{Pb})$ levels were detected in the muscle and skin of two commonly consumed fishes (Indo-Pacific king mackerel and Tiger-tooth croaker) in Bushehr Province in the Southwest of Iran. Heavy metal concentrations were determined using inductively coupled plasma (ICP). The mean contents of metal, expressed in $\mathrm{mg} / \mathrm{kg}$ wet wt., varied from 0.17 to 0.26 for $\mathrm{Cd}, 1.25$ to 1.84 for $\mathrm{Cu}, 0.6$ to 0.84 for $\mathrm{Ni}$ and 0.31 to 0.7 for $\mathrm{Pb}$. The highest and lowest contents of heavy metals in muscle and skin of both fish samples was $\mathrm{Cu}$ and $\mathrm{Cd}$, respectively, and heavy metal contents in both skin fish samples and muscle of Tiger-tooth croaker were found to decrease in as the order of $\mathrm{Cu}>\mathrm{Pb}>\mathrm{Ni}>\mathrm{Cd}$.

The fluoride $(\mathrm{F})$ content studied of the skin and muscle tissues of Indo-Pacific king mackerel (Scomberomorus guttatus) and tiger tooth croaker fish (Otolithes ruber) harvested commercially off the Bushehr shores of the Persian Gulf. By a standard diffusion procedure, the mean $\mathrm{F}$ concentration in the soft tissues of these two species of fish was determined to range from 5.56 to $6.09 \mathrm{mg} / \mathrm{kg}$ wet weight in the skin and 5.78 to $6.14 \mathrm{mg} / \mathrm{kg}$ wet weight in the muscles. At these concentrations, the total $F$ intake among consumers of the skin and muscle tissue of these fish is appreciably increased. Possibly contributing to these soft tissue levels, the mean $\mathrm{F}$ concentration of the water in this part of the Persian Gulf was measured at 1.97 mg/L (Dobaradaran et al., 2011).

The heavy metal contents determined in canned tuna fishes expressed in $\mu \mathrm{g} \mathrm{g}^{-1}$ wet wt., varied from 0.043 to 0.253 with an average value of 0.117 for mercury, from 0.0369 to 0.2618 with an average value of 0.128 for arsenic, 
from 0.0046 to 0.0720 with an average value of 0.0223 for cadmium, from 0.0126 to 0.0726 with an average value of 0.0366 for lead and was non-detectable for tin. Several samples were spiked with known amounts of metals. Recoveries of the metals were in the range of $91.7 \pm 2.89-$ $99.3 \pm 4.03$ (Emami Khansari et al., 2005).

Hajeb et al. (2010) observed that harmful substances, and toxic elements in long-tail tuna and shortbodied mackerel from Chendring, Kuantan, at east coast and Kuala Perlis. The sample of fishes were collected from west coast of Peninsular Malaysia. Total mercury and methylmercury in muscle of 69 fish samples of long-tail tuna and short-bodied mackerel, ranged from 0.180 to 1.460 $\mu \mathrm{g} / \mathrm{g}$ and $0.0169-0.973 \mu \mathrm{g} / \mathrm{g}$ and $0.251-1.470 \mu \mathrm{g} / \mathrm{g}$ and $0.202-1.352$, whereas the methylmercury to total mercury ratio ranged from $70 \%$ to $83 \%$, respectively.

The concentrations of mercury and other 13 metals in canned fish collected from Georgia and Alabama (United States of America). The ranges of elements analyzed as follows: $\mathrm{Hg}(0.02-0.74), \mathrm{Ag}(0.0-0.20)$, As (0.0-1.72), Cd (0.0-0.05), $\mathrm{Cr}(0.0-0.30), \mathrm{Fe}(0.01-88.4), \mathrm{Pb}(0.0-0.03), \mathrm{Mn}$ (0.01-2.55), Ni (0.0-0.78), Co (0.0-0.10), Cu (0.01-5.33), Sn (0.04-28.7), V (0.0-0.31) and Zn (0.14-97.8) (Ikem \& Egiebor 2005).

Irwandi et al. (2009) measured the concentrations of heavy metals $\mathrm{Hg}, \mathrm{Pb}$ and $\mathrm{Cd}$, in fin-fish Epinephelus sexfasciatus, Lutianus agentimaculatus, Cynoglossus lingua, Scolidon sorrakowah, Scomberomorus commersoni, Rastrelliger kanagurta, Psettodes crumei and Arius cumatranus. The fish caught off the Coast of Langkawi Island in Malaysia. Results showed that, all fish species had higher concentrations of $\mathrm{Zn}$ compared to other elements, $(\mathrm{Pb})$ and $(\mathrm{Hg})$ were found to have lower concentration.

Islam et al. (2010) observed heavy metal contaminants in fish, which are of particular interest because of the potential risk to humans who consume them. The edible muscles of eight different species of fishes collected from Market in Gwangju, Korea during April-May in 2008 were analyzed for heavy metals using Inductively Coupled Plasma Mass Spectroscopy. The concentrations of $\mathrm{Hg}$, As, $\mathrm{Cd}, \mathrm{Cr}, \mathrm{Cu}, \mathrm{Fe}, \mathrm{Mn}, \mathrm{Ni}, \mathrm{Pb}$ and $\mathrm{Zn}$ varied between $0.24 \pm 0.007,0.01 \pm 0.001,44.54 \pm 5.69,1.23 \pm 0.20,0.13 \pm 0.05-$ ND (not detected), 1.32 $\pm 0.47-0.09 \pm 0.02, \quad 3.13 \pm 2.53$, $0.63 \pm 0.06, \quad 107.17 \pm 28.02, \quad 11.27 \pm 1.56, \quad 12.38 \pm 1.23-$ $0.25 \pm 0.02,1.025 \pm 1.41-0.12 \pm 0.09,0.74 \pm 0.28-0.05 \pm 0.03$ and $80.30 \pm 17.09-22.35 \pm 6.89 \mathrm{mg} / \mathrm{kg}$, respectively. The concentrations of arsenic and nickel exceeded the maximum allowable intake level.
Jaffar et al. (1988) studied the concentration of $\mathrm{Ni}$, $\mathrm{Cu}, \mathrm{Mn}, \mathrm{Hg}, \mathrm{Fe}, \mathrm{Cr}, \mathrm{Cd}, \mathrm{Zn}, \mathrm{Pb}$, and $\mathrm{As}$ in 12 species of fishes. The fish sample collected from coastal waters of Pakistan, Arabian Sea. The levels of these metals were lowest in muscle but higher in liver and kidney. Nickel, $\mathrm{Cr}$, $\mathrm{Cd}, \mathrm{Pb}$, and $\mathrm{As}$ accumulated more in the liver than in the kidney. Silver pomfret (Pampus argenteus) and black pomfret (Formio niger) contained trace metal levels in the order kidney $>$ liver $>$ muscle. The trace metal levels in the pomfrets, the long-tail tuna (Thunnus tonggol), and the Indian oil sardine (Sardinella longiceps) were higher than in the other fish.

Kaladharan et al. (2006) measured trace metals in nine marine fishes. The sample was collected from Port Blair (Andamans) and at Kochi (Kerala, southwest coast). Samples from Kochi recorded as $1.42 \mu \mathrm{g} / \mathrm{g} \mathrm{Cd}$ and $271 \mu \mathrm{g} / \mathrm{g}$ $\mathrm{Fe}$ in Rastrelliger kanagurta, $11.3 \mu \mathrm{g} / \mathrm{g} \mathrm{Cu}$ in Sardinella gibbosa and $83.3 \mu \mathrm{g} / \mathrm{g} \mathrm{Pb}$ in S. rurnbil. Baring $\mathrm{Pb}$, significant correlation could not be established between the metal levels of sediment and water samples neither from Port Blair nor Kochi. Significant correlation could be established positively between water and Liza parsia, E. tauvina and S. longiceps as well as Pentaprion longimanus and $R$. kanagurta with sediment from Kochi.

The concentration of $\mathrm{Zn}, \mathrm{Cu}$ and $\mathrm{Pb}$ were measured in eight commercially valuable fish species, Selaroides leptolepis, Euthynnus affinis, Parastromateus niger, Lutjanius malabaricus, Epinephelus sexfasciatus, Rastrelliger kanagurta, Nemipterus japonicus and Megalaspis cordyla. Samples were collected from Pahang coastal water. The concentration was measured by (ICPMS). Concentrations of the heavy metals in examined fish species ranged as follow: $\mathrm{Zn} 19.27 \mu \mathrm{g} \mathrm{g}^{-1}$ dry weight; $\mathrm{Cu}$ $2.88 \mu \mathrm{g} \mathrm{g}^{-1}$ dry weight and $\mathrm{Pb} 0.26 \mu \mathrm{g} \mathrm{g}^{-1}$ dry weight, respectively. The concentrations of $\mathrm{Zn}, \mathrm{Cu}$ and $\mathrm{Pb}$ were found to follow the order: stomach $>$ muscle > gills (Kamaruzzaman et al., 2010).

Kerdthep et al. (2009) designed their study to determine the concentration of $(\mathrm{Cd})$ and (As) in 13 most consumed seafood species Decapterus maruadsi, Rastrelliger kanagurta, Nemipterus hexodon, Selaroides leptolepis, Scomberomorus commerson, Thunnus tonggol, Parastromateus niger, Epinephelus tauvina, Perna viridis, Arca granulose, Sepioteuthis lessoniana, Loligo duvauceli and Penaeus merguiensis collected from Muang District, Rayong Province. The concentration of cadmium in these seafood were $0.009-0.731 \mu \mathrm{g} / \mathrm{g}$ with the highest of 0.731 $\mu \mathrm{g} / \mathrm{g}$ in blood cockle (Arca granulosa). The concentration of arsenic in these seafood were $0.401-7.032 \mu \mathrm{g} / \mathrm{g}$, with the highest of $7.032 \mu \mathrm{g} / \mathrm{g}$ in soft cuttle fish (Sepioteuthis lessoniana). 
The distribution of eight heavy metals $(\mathrm{Cd}, \mathrm{Cr}, \mathrm{Cu}$, $\mathrm{Fe}, \mathrm{Mn}, \mathrm{Ni}, \mathrm{Pb}$ and $\mathrm{Zn}$ ) measured in five fish species namely, Sargus sargus, Siganus rivulatus, Mugil cephalus, Caranx crysos and Scomberomorus commerson collected from El-Mex Bay, Alexandria. The concentration was investigated in muscles, gills, livers and bones of fish (Khaled, 2004). Khaled (2004) also recorded that iron, zinc and copper were high concentration levels in liver while cadmium, chromium and lead were high in gills and bones. The concentrations of metals $(\mathrm{Cd}, \mathrm{Cu}$, and $\mathrm{Pb})$ in muscles of the five fishes are lower than the PTWI values, and accordingly there is no risk yet for human consumption of flesh of these fishes.

Khoshnood et al. (2012) determined the concentration of $\mathrm{Cd}, \mathrm{Pb}, \mathrm{Hg}, \mathrm{Cu}, \mathrm{Fe}, \mathrm{Mn}, \mathrm{Al}$, As, Ni, and $\mathrm{Zn}$ in Scomberomorous commerson, Rastrelliger kanagurta, Scomberomorus guttatus, Thannus tonggol, Pampus argenteus, Acanthopagrus latus, Argyrops spinifer, Mugile cephalus, Euryglossa orientalis, Psettodes erumei, Epinephelu coioides, Pomadasys kaakan, Lutjunus johnii and Sardinella sindensis. The fish samples were collected from Hormoz Strait in North Coast of Persian Gulf. All samples were analyzed for $\mathrm{Cd}, \mathrm{Pb}, \mathrm{Cu}, \mathrm{Fe}, \mathrm{Mn}, \mathrm{Al}, \mathrm{As}, \mathrm{Ni}$ and $\mathrm{Zn}$ concentrations by ICP-AES and for $\mathrm{Hg}$ by LECO AMA254 Advanced Mercury Analyzer. Results of the study showed, iron had the highest total mean concentration in all species, and followed by $\mathrm{Zn}, \mathrm{Cu}, \mathrm{Ni}, \mathrm{Al}, \mathrm{Pb}, \mathrm{Mn}, \mathrm{Cd}$ and $\mathrm{Hg}$ and lowest concentration in three tissues was in addition accumulation of metals was species-dependent, and was higher in Scomberomorous commerson and Thannus tonggol $(\mathrm{p}<0.05)$ and the lowest concentration was recorded in Sardinella sindensis $(\mathrm{p}<0.05)$.

Kojadinovic et al. (2007) trace elements were analyzed in fish of commercial interest to determine their importance in marine systems of the Western Indian Ocean and their bioaccumulation patterns. The results were equivalent or lower than levels reported in ichthyofauna in other seas. Certain values of muscular $\mathrm{Cd}, \mathrm{Hg}, \mathrm{Pb}$ and $\mathrm{Zn}$ were, however, above thresholds for human consumption. Levels varied among tissues, species and fish length, but were seldom influenced by the nutritional condition of the fish, its gender and its reproductive status. Correlations between hepatic $\mathrm{Hg}$ and Se levels in swordfish $\left(\mathrm{r}^{2}=0.747\right)$ and yellowfin tunas $\left(\mathrm{r}^{2}=0.226\right)$, and among metallothionein linking metals imply the existence of detoxification processes in these species. Level differences between fish from the Mozambique Channel and Reunion Island reflect differences of diets rather than differences of elemental availability in both environments.

Krishna Kumar et al. (1990) studied the trace metal concentration of $\mathrm{Cd}, \mathrm{Pb}, \mathrm{Cu}, \mathrm{Zn}$ and $\mathrm{Mn}$ in fishes, oyster
(Crassostrea cucullata), mussel (Pema viridis) mackerel (Rastrelliger kanagurta) and seaweed (Sargassum tenerimum) collected from the vicinity of discharge point were found to be comparatively high. It was found that oysters were more effective bio-accumulators of $\mathrm{Zn}, \mathrm{Cu}$, and $\mathrm{Cd}$, while mussels and seaweeds were of $\mathrm{Pb}$ and $\mathrm{Mn}$.

The concentration level of lead, cadmium, nickel and zinc in sixteen brands of canned tuna, collected from southern Iran. The metal contents, expressed in $\mu \mathrm{g} \mathrm{g}^{-1}$ wet weight for nickel, cadmium, zinc and lead varied from 0.14 to 0.7 (average of $0.4098 \pm 0.2$ ), 0.05 to 0.16 (average of $0.3519 \pm 0.019$ ), 0.41 to 1.7 (average of $0.77 \pm 0.36$ ) and 0.11 to 0.3 (average of $0.2115 \pm 0.11$ ), respectively (Malakootian et al., 2011).

Meaburn (1978) determined heavy metal concentrations in Spanish mackerel, Scomberomorus maculatus, and king mackerel, S. cavalla, collected from coastal waters of southeastern United States. Data are presented on heavy metal concentrations found in individual mackerels taken from ten locations in coastal waters of southeastern United States, with emphasis on the occurrence of mercury and methylmercury. The inter-relationships between mercury levels and fish sizes were described quantitatively.

Mol (2011) studied the trace element iron, zinc, copper, cadmium, tin, mercury and lead concentration were measured in canned tuna collected from Turkey. The heavy metals were found to be in the range of $20.2-38.7 \mathrm{mg} / \mathrm{kg}$ for iron, $8.20-12.4 \mathrm{mg} / \mathrm{kg}$ for zinc $0.48-0.58 \mathrm{mg} / \mathrm{kg}$ for copper, $0.01-0.02 \mathrm{mg} / \mathrm{kg}$ for cadmium, $0.02-0.13 \mathrm{mg} / \mathrm{kg}$ for tin, $0.06-0.30 \mathrm{mg} / \mathrm{kg}$ for mercury, and $0.09-0.45 \mathrm{mg} / \mathrm{kg}$ for lead.

The heavy metal concentrations cadmium, mercury and arsenic determined in six marine fish species, Bombay duck (Harpadon nehereus), Bhola (Daysciaena albida), white pomfret (Pumpus argentius), black pomfret (Formio niger), Hilsa (Hilsa ilisha), and mackerel (Rastrelliger kanagurta). The fish sample collected from north eastern Bay of Bengal, India. The concentrations level of arsenic, cadmium and mercury were in range of $0.02-2.34 \mu \mathrm{g} / \mathrm{g}$, $0.01-2.10 \mu \mathrm{g} / \mathrm{g}$ and $0.07-1.60 \mu \mathrm{g} / \mathrm{g}$ dry wt., respectively. Arsenic was the highest followed by mercury and cadmium and their average concentrations were $0.66 \pm 0.09 \mu \mathrm{g} / \mathrm{g}$, $0.62 \pm 0.05 \mu \mathrm{g} / \mathrm{g}$ and $0.47 \pm 0.07 \mu \mathrm{g} / \mathrm{g}$ dry wt., respectively (Mukherjee et al., 2011).

Nair et al. (2006) observed the concentration of Zn, $\mathrm{Cd}, \mathrm{Pb}$, and $\mathrm{Mn}$ in 17 species of fish collected from tropical estuary (Cochin backwaters). The gills indicated low level of metal concentration compared with muscles and liver. Nor Hasyimah et al. (2011) observed that, the assessment of 
$\mathrm{Cd}$ and $\mathrm{Pb}$ levels in commercial fish organs of (Rastrellinger kanagurta, Epinephelus sexfasciatus, Lates calcarifer and Decapterus maruadsi). Sample of fishes collected from different markets of Klang Valley, Malaysia. Results showed that $\mathrm{Cd}$ and $\mathrm{Pb}$ in fishes sampled from supermarkets was generally higher compared to wet markets, while both metals content in the edible organs fell well within the permissible limits for human consumption when compared to the 1985 Fourteenth Schedule of the Malaysian Food Regulations.

The concentration of $\mathrm{Fe}, \mathrm{Co}, \mathrm{Ni}, \mathrm{Cu}, \mathrm{Zn}, \mathrm{Cd}$, and $\mathrm{Pb}$ in marine fishes Lates calcarifer, Nemipterus japonicus, Caranx melampygus, Rastrelliger kanagurta and Cyanoglossus macrostomus was studied by Rejomon et al. (2010). These fish samples were collected from continental shelf waters off Kochi and Mangalore on southwest coast of India. The concentration level ranges of $\mathrm{Fe}$ (541.60 to 649.60 ppm), Ni (12.12 to $13.92 \mathrm{ppm}$ ), and $\mathrm{Cu}$ (3.09 to 3.62 ppm) were higher in the demersal species C. melampygus, whereas Co (9.10 to $11.80 \mathrm{ppm})$ and $\mathrm{Zn}$ (79.30 to 84.30 ppm) were higher in the pelagic species $L$. calcarifer and $\mathrm{Cd}$ (4.35 to $6.38 \mathrm{ppm}$ ) was higher in the demersal species $N$. japonicas. Among the demersal species, C. melampygus and $N$. japonicus had high concentration factors for the metals $\mathrm{Fe}(280,268$ to 322,808$), \mathrm{Ni}(88,252$ to 96,891$), \mathrm{Cu}(2,351$ to 2,600$)$, and $\mathrm{Cd}(29,637$ to 32,404$)$. In contrast, the pelagic species $L$. calcarifer and $R$. kanagurta had high concentration factors for the metals $\mathrm{Zn}(40,812$ to 46,892), $\mathrm{Co}(280,285$ to 423,037$)$, and $\mathrm{Pb}(854$ to 1,404$)$ (Rejomon et al., 2010).

Saei-Dehkordi and Fallah (2011) observed the concentration of cadmium, lead, copper and zinc in fish species (Scomberomorus commerson, Chirocentrus dorab, Sphyraena jello, Rachycentron conadum, Thunus tonggol, and Tenualosa ilisha) and demersal (Nemipterus japonicas, Epinephelus coioides, Platycephalus indicus, Psettodes erumei, Pomadasys argenteus, and Acanthopagrus latus) collected from Persian Gulf. The level of metal concentrations was in the range of $0.024-0.111 \mu \mathrm{g} / \mathrm{g}$ for cadmium, 0.057-0.471 $\mu \mathrm{g} / \mathrm{g}$ for lead, $0.799-4.790 \mu \mathrm{g} / \mathrm{g}$ for copper and 3.226-11.390 $\mu \mathrm{g} / \mathrm{g}$ for zinc. The maximum concentrations of cadmium, lead, copper and zinc was found in Platycephalus indicus $(0.147 \mu \mathrm{g} / \mathrm{g})$, Acanthopagrus latus $(0.534 \mu \mathrm{g} / \mathrm{g})$, Psettodes erumei $(5.294 \mu \mathrm{g} / \mathrm{g})$ and Psettodes erumei $(13.528 \mu \mathrm{g} / \mathrm{g})$ in winter, respectively.

Sivaperumal et al. (2007) determined that heavy metal $\mathrm{Cd}, \mathrm{Pb}, \mathrm{Hg}, \mathrm{Cr}, \mathrm{As}, \mathrm{Zn}, \mathrm{Cu}, \mathrm{Co}, \mathrm{Mn}, \mathrm{Ni}$, and $\mathrm{Se}$ concentration in Etroplus suratensis, Labeo rohita, Chanos chanos, Etroplus suratensis, Scomberomorus guttatus, Catla catla, Saurida sp., Otolithus sp., Euthynnus affinis, Pompus argenteus, Etroplus suratensis and Oreochromis mossambicus shellfish and fish products. The concentration ranges of $\mathrm{Cd}, \mathrm{Pb}, \mathrm{Hg}, \mathrm{Cr}, \mathrm{As}, \mathrm{Zn}, \mathrm{Cu}, \mathrm{Co}, \mathrm{Mn}, \mathrm{Ni}$, and $\mathrm{Se}$ in the samples were $<0.07-1,<0.07-1.32,<0.05-2.31,<0.05$ to $3.65,<0.1-4.14,0.6$ to $165,0.15$ to $24,<0.02$ to $0.85,<0.08$ to $9.2,<0.032-1.38$ and; $<0.03-1.35 \mathrm{mg} / \mathrm{kg}$, respectively.

Sobhanardakani et al. (2011) investigated the concentration level of $\mathrm{Pb}, \mathrm{Hg}$ and $\mathrm{As}$ in Otolithes rubber, Pampus argenteus, Parastromateus niger, Scomberomorus commerson and Onchorynchus mykiss of the muscle, gill and liver. It was found that mercury concentration was highest in the gill of Parastromateus niger $(0.47 \mu \mathrm{g} / \mathrm{g})$ followed by the liver of Otolithes rubber $(0.001 \mu \mathrm{g} / \mathrm{g})$, lead content was maximum in the gill of Parastromateus niger $(0.11 \mu \mathrm{g} / \mathrm{g})$, followed by the liver of Scomberomorus commerson $(0.005 \mu \mathrm{g} / \mathrm{g})$, arsenic concentration is highest in the liver of Otolithes rubber $(0.26 \mu \mathrm{g} / \mathrm{g})$, followed by the muscle of Pampus argenteus $(0.007 \mu \mathrm{g} / \mathrm{g})$. The results of that study indicated that the concentration of $\mathrm{Pb}, \mathrm{Hg}$ and $\mathrm{As}$ in the different tissues of the studied marine organisms were significantly lower than permissible levels these toxic metals.

Sofia (2005), determined the concentration of $\mathrm{Cd}$, $\mathrm{Pb}, \mathrm{Cu}$ and $\mathrm{Cr}$ levels in fish (A. mate, R. kanagurta, E. affinis, L. surinamensis and E. coioides) and in the muscle of one species of shrimp ( $P$. coromandelica). The concentrations of metals were measured in muscle, liver and kidney tissues of fish. The fish samples were found to contain Cd levels ranging from 0.01 to $0.83 \mu \mathrm{g} / \mathrm{g}$ (dry wt.) with the highest level recorded in the tuna (E. affinis). The maximum $\mathrm{Pb}$ levels were recorded in the same species and concentrations ranged from 0.02 to $0.73 \mu \mathrm{g} / \mathrm{g}$ (dry wt.). Concentrations from 0.03 to $4.7 \mu \mathrm{g} / \mathrm{g}$ dry wt. were recorded for $\mathrm{Cu}$ with the highest levels found in the grouper ( $E$. coioides). The levels of between 0.03 to $2.09 \mu \mathrm{g} / \mathrm{g}$ dry wt. were detected for $\mathrm{Cr}$ with the highest accumulation recorded in the mackerel ( $R$. kanagurta). In the shrimp ( $P$. coromandelica) samples, the highest metal content was detected for $\mathrm{Cu}$, which ranged from 1.25 to $2.84 \mu \mathrm{g} / \mathrm{g}$ dry wt. followed by $\mathrm{Cr}$, the values for which, ranged between 0.14 to $1.1 \mu \mathrm{g} / \mathrm{g}$ (dry wt.). Cd levels ranged from 0.01 to $0.06 \mu \mathrm{g} / \mathrm{g}$ (dry wt.) while $\mathrm{Pb}$ levels ranged from 0.01 to 0.09 $\mu \mathrm{g} / \mathrm{g}$ dry wt.

The concentration level of $(\mathrm{Cu}, \mathrm{Fe}, \mathrm{Mg}, \mathrm{Mn}, \mathrm{Ni}$, $\mathrm{Zn}$ ) determined in kidney of Bluefin tuna Thnunnus thynnus collected from sub-tropical regions of Turkish seas (Sogut \& Percin, 2011).

Srebocan et al. (2007) observed the levels of total mercury in Bluefin tuna (Thunnus thynnus) weighing 100$300 \mathrm{~kg}$ determined by cold vapor atomic absorption spectroscopy (AAS). Tunas were previously captured in the 
waters of Malta, towed to the farm in the Adriatic Sea and fattened with defrosted herring and sardine for the period of 6 to 7 months. Total mercury concentrations in the muscle tissue of tunas ranged from 0.49 to 1.809 with mean 0.899 $\mu \mathrm{g} / \mathrm{g}$ wet wt. while in the liver tissue it was from 0.324 to 3.248 with mean $1.165 \mu \mathrm{g} / \mathrm{g}$ wet wt. Total mercury concentrations in six samples of sardine ranged from 0.050 to $0.072 \mu \mathrm{g} / \mathrm{g}$ wet wt. while two samples of herring contained 0.020 and $0.053 \mu \mathrm{g} / \mathrm{g}$ wet wt.

Sireli et al. (2006) measured cadmium (Cd) and lead $(\mathrm{Pb})$ concentrations in (Salmo salar and Oncorhynhus mykiss) collected from Ankara market. Trace metal concentrations were measured by GFAAS. The ranges of the metals were found for $\mathrm{Cd} 0.003-0.036 \mathrm{mg} \mathrm{kg}^{-1}$ dry weight, while that for $\mathrm{Pb}$ was $0.001-0.791 \mathrm{mg} \mathrm{kg}^{-1}$ dry weight. Cadmium concentrations in all fish species analyzed were below $0.05 \mathrm{mg} \mathrm{kg}^{-1}$ the limit specified by Turkish and EU legislation, whereas $\mathrm{Pb}$ levels in 27 fish samples (36.9\%) exceeded the Turkish acceptable limit of $0.2 \mathrm{mg} \mathrm{kg}$. However, Sireli et al. (2006) pointed out that at even the highest heavy metal concentrations measured, the estimated weekly intakes of $\mathrm{Cd}$ and $\mathrm{Pb}$ for a60 kg adult consuming $400 \mathrm{~g}$ of fish per week would be below the provisional tolerable weekly intakes recommended by the Joint FAO/WHO Expert Committee of $7 \mu \mathrm{g} \mathrm{kg}^{-1}$ body weight for $\mathrm{Cd}$ and $25 \mu \mathrm{g} \mathrm{kg}^{-1}$ body weights for $\mathrm{Pb}$.

Tariq et al. (1993) studied eleven heavy metal concentrations in fish (Rastrelliger kanagurta, Pomadysis maculatum and Chactadon jayakeri), shrimp, seaweed, sediment, and water collected from ten sites off the coastal area bounded by the mouth of the Indus River in the Arabian Sea, Pakistan. Authors selected these organisms to make on the basis of both ecological and metal pollution assessment points of size-controlled batches, together with sediment and water samples.

Tüzen and Soylak (2007) observed the amounts of metals of canned anchovy fish, canned tuna fish, canned Black Sea bonito, canned sardine and canned Atlantic horse mackerel. The fish species captured from markets in Turkey. The results of the canned fish samples were 1.10-2.50 $\mu \mathrm{g} / \mathrm{g}$ for copper, 7.57-34.4 $\mu \mathrm{g} / \mathrm{g}$ for zinc, $0.90-2.50 \mu \mathrm{g} / \mathrm{g}$ for manganese, $10.2-30.3 \mu \mathrm{g} / \mathrm{g}$ for iron, $0.96-3.64 \mu \mathrm{g} / \mathrm{g}$ for selenium, $0.45-1.50 \mu \mathrm{g} / \mathrm{g}$ for aluminum, $0.97-1.70 \mu \mathrm{g} / \mathrm{g}$ for chromium, $0.42-0.85 \mu \mathrm{g} / \mathrm{g}$ for nickel, $0.09-0.40 \mu \mathrm{g} / \mathrm{g}$ for lead and $0.06-0.25 \mu \mathrm{g} / \mathrm{g}$ for cadmium.

Turkmen et al. (2009) observed metal levels in muscles and livers of twelve fish species Pagellus acarne, Trigla lyra, Serranus scriba, Scomber japonicus, Scyliorhinus canicula, Pomadasys incisus, Uranoscopus scaber, Liza ramado, Dicentrarchus labrax, Trachinotus ovatus, Pagrus caeruleostictus and Sphyraena viridensis from Aegean Sea and Mediterranean Sea. The levels of $\mathrm{Cd}$, $\mathrm{Co}, \mathrm{Cr}, \mathrm{Cu}, \mathrm{Fe}, \mathrm{Mn}, \mathrm{Ni}, \mathrm{Pb}$ and $\mathrm{Zn}$ in muscles of fish were $<0.01-0.39$, <0.01-0.45, 0.07-1.48, 0.51-7.05, 9.18-136, $0.18-2.78,0.03-1.72,0.21-1.28$ and $3.51-53.5 \mathrm{mg} \mathrm{kg}^{-1}$, respectively.

Vijayakumar et al. (2011) studied the concentration of $\mathrm{Cu}, \mathrm{Cr}, \mathrm{Cd}, \mathrm{Co}, \mathrm{Ni}$ and $\mathrm{Zn}$ in three fish species Rastrilleger kanagurta, Kathala axillaries and Sardinella longiceps. The fish samples were collected from Cuddalore along Tamil Nadu coast, Bay of Bengal, India.

Heavy metals analyzed in 40 fishes were collected from Karachi Fish Harbor during the period from (September, 2008 to August, 2009). Heavy metal (Cu, Zn, $\mathrm{Mn}$ and $\mathrm{Fe}$ ) concentrations were measured in the liver and muscles of fish (Thunnus tonggol) by atomic absorption spectrophotometry by the dry ashing method. The liver of Thunnus toggol shows higher concentration of metals in all seasons of the year. Highest concentration of $\mathrm{Cu}$ (245.86 $\mu \mathrm{g} / \mathrm{g})$ were recorded in liver in the autumn season. Maximum concentration of $\mathrm{Zn}(27.42 \mu \mathrm{g} / \mathrm{g})$ were recorded in liver in summer season. However in all season concentration of $\mathrm{Fe}, \mathrm{Zn}, \mathrm{Cu}$, and $\mathrm{Mn}$ in liver were higher than muscles. Metal accumulated very rapidly in the fish liver but slowly in the fish flesh. No significant correlation between metal levels in muscles and liver and length and weight of fish. The decreasing order of concentration of metals in liver was $\mathrm{Cu}>\mathrm{Mn}>\mathrm{Fe}>\mathrm{Zn}$ and in muscles $\mathrm{Cu}>$ $\mathrm{Zn}>\mathrm{Mn}>\mathrm{Fe}$ (Yousuf \& Ahmed, 2010).

Yousuf and Ahmed (2011) also studied the amounts of heavy metals namely zinc, manganese, copper and iron in liver and muscles of 72 sample of Rastrelliger kanagurta, collected during April 2008- March 2009 from Karachi Fish Harbor on monthly basis. The metal levels were found to be generally higher in liver than in muscles of fish. In fish liver maximum mean concentration of $\mathrm{Fe}$ $45.668 \mu \mathrm{g} / \mathrm{g}^{-1}, \mathrm{Zn} 23.36 \mu \mathrm{g} / \mathrm{g}^{-1}, \mathrm{Cu} 5.006 \mu \mathrm{g} / \mathrm{g}^{-1}$, and $\mathrm{Mn}$ $3.273 \mu \mathrm{g} / \mathrm{g}^{-1}$ and the lowest mean concentrations of these metals were $12.056 \mu \mathrm{g} / \mathrm{g}^{-1}, 3.247 \mu \mathrm{g} / \mathrm{g}^{-1}, 1.14 \mu \mathrm{g} / \mathrm{g}^{-1}$, and $0.477 \mu \mathrm{g} / \mathrm{g}^{-1}$ respectively. In muscles of fish highest mean concentrations of Fe was $12.74 \mu \mathrm{g} / \mathrm{g}^{-1}, \mathrm{Zn} 12.71 \mu \mathrm{g} / \mathrm{g}^{-1}, \mathrm{Cu}$ $9.81 \mu \mathrm{g} / \mathrm{g}^{-1}$, and $\mathrm{Mn} 3.67 \mu \mathrm{g} / \mathrm{g}^{-1}$ and lowest mean concentrations of these metals were $5.89 \mu \mathrm{g} / \mathrm{g}^{-1}, 4.53 \mu \mathrm{g} / \mathrm{g}^{-1}$, $1.94 \mu \mathrm{g} / \mathrm{g}^{-1}$ and $0.17 \mu \mathrm{g} / \mathrm{g}^{-1}$, respectively. The concentration of all metals varied significantly in different months.

Zarei et al. (2010) studied the heavy metals concentration in canned tuna fish samples and found to be in the range of $0.007-0.51 \mu \mathrm{g} / \mathrm{g}$ for lead, $0.002-0.07 \mu \mathrm{g} / \mathrm{g}$ for cadmium, $0.023-13.108 \mu \mathrm{g} / \mathrm{g}$ for tin, $0.17-8.001 \mu \mathrm{g} / \mathrm{g}$ for 
copper, 0.124-27.001 $\mu \mathrm{g} / \mathrm{g}$ for zinc and 0.009-14.207 $\mu \mathrm{g} / \mathrm{g}$ for iron.

\section{OVERALL CONCLUSION}

Most of studies showed that essential metals in fish species are much higher than those in non-essential metals. Since $\mathrm{Fe}, \mathrm{Zn}, \mathrm{Cu}$ and $\mathrm{Mn}$ are essential trace elements especially with regard to many enzymatic reactions it is possible that the uptake of these trace elements is associated with the metabolic activity (Bat et al., 1998-1999). Moreover, essential trace elements are important components of the human body (Underwood, 1977), but if they exist in levels exceeding certain limits they become very toxic to most forms of organisms (Bat \& Raffaelli, 1998).

Heavy metal levels in liver and in digestive system tract tissues or organs offish are also higher than those in edible muscles at significant levels. Many studies argued that liver is the main detoxification destiny and one of the most important metal storage organs by the digestive tract (Agusa et al., 2007; Farkas et al., 2002; Jaffar et al., 1988; Khaled, 2004; Krishna Kumar et al., 1990; Sobhanardakani et al., 2011; Sofia, 2005; Turkmen et al., 2009; Yousuf \& Ahmed, 2010; Bat et al., 2012). It should be kept in mind that the most metals especially non-essentials stored in the liver and kidney depends on the intensity of exposure time and state of renal excretory function. However, consumers mainly don't eat the liver of fish.

The changeability of the metals in fish can be explained that the regulation of heavy metals are depending on many factors such as type of the metal, residence time in the surrounding, time of exposure, amounts, physiology, metabolism, morphology, size and age of the fish and the physical and chemical properties of receiving water. There also come into being inter individual responses of fish, even induce that reactions may be because of the adaptive capacity of individuals to contaminated environments (Noreña-Ramirez et al., 2012). It should be also pointed out that the variability of metal levels in the same species depends on their habitats. For example, many pelagic fish species migrate frequently between saltwater, estuaries and freshwater, whereas many benthic species live in association with sediment. The many fish species occupy different layers of the water column. These templates confirm that the differences in metal levels in various fish species could greatly be based on the differences in feed habits. It may be suggested that feeding way act basic and significant part in the control of heavy metal accumulation (Abdolahpur et al., 2013).
In Pakistan, for example, during the monsoon period from June to September, monsoon winds carry moisture from the Indian Ocean and bring heavy rains. The pre and post monsoon seasons affect the seawater and mobilize sea life. Therefore, these changes affect directly or indirectly to the life of marine fish (Ahmed et al., 2012).

It is most probable that short-term exposure to the heavy metals do not reason exact health risk to humans. Therefore, the total average annual effective dose due to intake of heavy metals from fish as food is important issues for infant, children and adults. As results, the estimated metal dose (EDI) values for daily average consumption and hazarded quotients (HI) in fish samples should be calculated to determine and monitor the serious health risks due to the consumption of contaminated fish.

Now, it is well understood that fish are used as a bio-indicator to evaluate the health of aquatic ecosystems since heavy metals accumulate in food. Bat (2014) suggested that it would be useful to carry out in detailed, extensive observations to monitor this situation in the future specially around industrial centers and ports and reference areas and their impact on the environment.

\section{REFERENCES}

Abdolahpur, M.F., Safahieh, A., Savari, A. \& Doraghi, A. (2013). Heavy metal concentration in sediment, benthic, benthopelagic, and pelagic fish species from Musa Estuary (Persian Gulf). Environ. Monit. Assess., 185, 215-222. doi:10.1007/s10661-0122545-9.

Adams, D.H. \& McMichael R.H. (2007). Mercury in king mackerel, Scomberomorus cavalla, and Spanish mackerel, S. maculatus, from waters of the southeastern USA, regional and historical trends. Marine and Freshwater Research, 58, 187-193.

Agusa, T., Kunito, T., Sudaryanto, A., Supawat, KanAtireklap., Iwata, H., Ismail, A., Sanguansin, J., Muchtar, M., Tana, T.S. \& Tanabe, S. (2007). Exposure assessment for trace elements from consumption of marine fish in Southeast Asia. Environmental Pollution, 145, 766-777.

Agency for Toxic Substances and Disease Registry (ATSDR) (2002). Toxicological profile for Aldrin/Dieldrin. Atlanta, GA: U.S. Department of Health and Human Services, Public Health Service, 297 pp.

Ahmed, M. \& Abdallah, M. (2008). Trace element levels in some commercially valuable fish species from coastal waters of Mediterranean Sea, Egypt, Journal of Marine Systems, 73, 114-122. 
Ahmed, Q., Bat, L. \& Mohammad Ali, Q. (2012). Heavy metal levels in Thunnus albacares (Bonnaterre, 1788) from Karachi fish harbour, Pakistan. Pakistan Journal of Marine Sciences, 21(1\&2), 1321.

Ahmed, Q., Yousuf, F., Sarfraz, M., Ali, Q.M., Balkhourd, M., Safie, S.Z \& Ashraf, M.A. (2014). Euthynnus affinis (little tuna): fishery, bionomics, seasonal elemental variations, health risk assessment and conservational management, Frontiers in Life Science, Frontiers in Life Science, http://dx.doi.org/10.1080/21553769.2014.961617.

Ahmed, Q., Yousuf, F., Sarfraz, M., Abu Bakar, N.K., Balkhour, M.A \& Ashraf, M.A. (2014). Seasonal elemental variations of $\mathrm{Fe}, \mathrm{Mn}, \mathrm{Cu}$ and $\mathrm{Zn}$ and conservational management Rastrelliger kanagurta fish from Karachi fish harbour, Pakistan, Journal of Food, Agriculture \& Environment, 12 (3\&4), 405414.

Ahmed, Q., Bat, L., Yousuf, F., Ali, Q.M \& Nazim, K. (2015). Accumulation of heavy metals ( $\mathrm{Fe}, \mathrm{Mn}, \mathrm{Cu}$, $\mathrm{Zn}, \mathrm{Ni}, \mathrm{Pb}, \mathrm{Cd}$ and $\mathrm{Cr}$ ) in Tissues of narrow-barred Spanish mackerel (Family-Scombridae) Fish Marketed by Karachi Fish Harbor, Open Biological Sciences Journal, 1, 20-28.

Ahmed, Q., \& Bat, L. (2015). Mercury (Hg) levels in Indian mackerel Rastrelliger kanagurta (Scombridae) from Karachi fish harbour and its risk assessment, Journal of fisheries sciences.com, 9(1), 356-360.

Ahmed, Q., Benzer, S. \& Yousuf, F. (2016). Distribution of heavy metals in different tissues of Indian mackerel from Karachi fish harbour, Karachi, Pakistan, Indian J. Anim. Res., 50 (5), 759-763.

Ahmed, Q., Bat, L. \& Yousuf, F. (2017). Contamination of $\mathrm{Cu}, \mathrm{Zn}, \mathrm{Fe}$ and $\mathrm{Mn}$ in Katsuwonus pelamis (Linnaeus, 1758) from Karachi fish harbor and potential risks to human health, International Journal of Marine Science, 7, 9. doi: 10.5376/ijms.2017.07.0009.

Al-Shwafi, N.A.A. (2002). Heavy metal concentration levels in some fish species in the Red Sea and Gulf of Aden-Yemen. Qatar University Science Journal, 171-176.

Alina, M., Azrina, A., Mohd Yunus, A.S., Mohd Zakiuddin, S., Mohd Izuan Effendi, H. \& Muhammad Rizal, R. (2012). Heavy metals (mercury, arsenic, cadmium, plumbum) in selected marine fish and shellfish along the Straits of Malacca. International Food Research Journal, 19, 59-66.

Appenroth, K.J. (2010). Chapter 2 Definition of "Heavy metals" and their role in biological systems. In: I. Sherameti and A. Varma (eds.), Soil Heavy Metals.
Soil Biology, 19,19-29. doi: 10.1007/978-3-64202436-8_2.

Ashraf, W., Seddigi, Z., Abdallah, A. \& Khalid, M. (2006). Level of selected metals in canned fish consumed in Kingdom of Saudi Arabia. Earth and Environmental Monitoring and Assessment, 117, 271-279.

Bae, J.H. \& Lim, S.Y. (2012). Effect of season on heavy metal contents and chemical compositions of chub mackerel (Scomber japonicus) muscle, Journal of Food Science, 77, 52-57.

Baloch, A.B., Ahmed, Q., Mohammad Ali, Q., Bat, L. \& Bilgin, S. (2012). Seasonal variation of condition factor and weight-length relationship in Thryssa hamiltonii Gray, 1835 (Clupeiformes: Engraulidae) collected from the Balochistan coast of the Arabian Sea, Pakistan. Pakistan Journal of Marine Sciences, 21(1\&2), 29-35.

Bat, L. \& Raffaelli, D. (1998). Sediment toxicity testing: A bioassay approach using the amphipod Corophium volutator and the polychaete Arenicola marina. $J$. exp. mar. Biol. Ecol., 226, 217-239.

Bat, L., Gündogdu, A. \& Oztürk, M. (1998-1999). Heavy metals. S.D. Ü. Egirdir Su Ürünleri Fak. Der., 6, 166-175. (in Turkish).

Bat, L., Gündogdu, A., Yardım, Ö., Zoral, T. \& Çulha, S. (2006). Heavy metal amounts in zooplankton and some commercial teleost fish from inner harbour of Sinop, Black Sea. SÜMDER (Su Ürünleri Müh. Dergisi) 25, 22-27 (in Turkish)

Bat, L., Şahin, F., Üstün, F. \& Sezgin, M. (2012). Distribution of $\mathrm{Zn}, \mathrm{Cu}, \mathrm{Pb}$ and $\mathrm{Cd}$ in the tissues and organs of Psetta maxima from Sinop coasts of the Black Sea, Turkey. Marine Science, 2(5),105-109. doi: 10.5923/j.ms.20120205.10.

Bat, L. (2014). Heavy metal pollution in the Black Sea. In: Düzgünes E, Oztürk B, Zengin M. (Eds.). Turkish Fisheries in the Black Sea. Published by Turkish Marine Research Foundation (TUDAV), Publication number: 40, ISBN: 987-975-8825-32-5 Istanbul, Turkey, p. 71-107.

Bat, L., \& Arıcı, E. (2018). Heavy metal levels in fish, molluscs and crustacea from Turkish seas and potential risk of human health. In: Handbook of Food Bioengineering, 159-196pp. https://doi.org/10.1016/B978-0-12-8114421.00005-5.

Bebbington, G.N., Mackay, N.J., Chvojka, R., Williams, R.J., Dunn, A. \& Auty, E.H. (1977). Heavy metals, selenium and arsenic in nine species of Australian commercial fish Australian Journal of Marine and Freshwater Research, 28, 27-286.

Bhupander, K., Sajwan, K.S. \& Mukherjee, D.P. (2012). Distribution of heavy metals in valuable coastal 
fishes from north east coast of India. Turkish Journal of Fisheries and Aquatic Sciences, 12, 8188.

Biswas, S., Prabhu, R.K., Hussain, K.J., Selvanayagam, M. \& Satpathy, K.K. (2012). Heavy metals concentration in edible fishes from coastal region of Kalpakkam, south-eastern part of India. Environment Monitoring and Assessment, 184, 5097-104.

Castro-Gonzalez, M.I. \& Mendez-Armenta, M. (2008). Heavy metals implications associated to fish consumption. Environmental Toxicology and Pharmacology, 26, 263-271.

CDGK (2012). City district Government of Karachi. www.karachicity.gov.pk.

Celik, U. \& Oehlenschlager, J. (2004). Determination of zinc and copper in fish samples collected from Northeast Atlantic by DPSAV, Food Chemistry, 87, 343-347.

Chandrashekar, K. \& Deosthale, Y.G. (1993). Proximate composition, amino acid, mineral, and trace element content of the edible muscle of 20 Indian fish species. Journal of Food Composition and Analysis, 6, 195-200.

Deshpande, A., Bhendigeri, S., Shirsekar, T., Dhaware, D. \& Khandekar, R.N. (2009). Analysis of heavy metals in marine fish from Mumbai Docks. Environmental Monitoring Assessment, 159, 493500.

Dobaradaran, S., Naddafi, K., Nazmara, S. \& Ghaedi, H. (2010). Heavy metals $(\mathrm{Cd}, \mathrm{Cu}, \mathrm{Ni}$ and $\mathrm{Pb})$ content in two fish species of Persian Gulf in Bushehr Port, Iran. African Journal of Biotechnology, 9, 61916193.

Dobaradaran, S., Vakil Abadi, D. R., Mahvi, A. H. \& Javid, A. (2011). Fluoride in skin and muscle of two commercial species of fish harvested off the bushehr shores of the Persian Gulf. Research report Fluoride, 44, 143-146.

EFSA (2012a). Cadmium dietary exposure in the European population. EFSA Journal, 10(1), 2551, 37 pp. doi: 10.2903/j.efsa.2012.2551.

EFSA Panel on Contaminants in the Food Chain (CONTAM) (2012b). Scientific opinion on the risk for public health related to the presence of mercury and methylmercury in food. EFSA Journal, 10(12), 2985, 241 pp., doi: 10.2903/j.efsa.2012.2985.

EFSA (2012c). Lead dietary exposure in the European population. EFSA Journal, 10(7), 2831, 59 pp. doi: 10.2903/j.efsa.2012.2831.

Emami Khansari, F., Ghazi-Khansari, M. \& Abdollahi, M. (2005). Heavy metals content of canned tuna fish. Food Chemistry, 93, 293-296.
Farkas, A., Salanki, J. \& Specziar, A. (2002). Relation between growth and the heavy metal concentration in organs of bream Abramis brama L. populating Lake Balaton, Archives Environmental Contamination Toxicology, 43, 236-43.

Hajeb, P., Jinap, S. \& Ahmad, I. (2010). Biomagnifications of mercury and methylmercury in tuna and mackerel. Centre of Excellence for Food Safety Research (CEFSR), Faculty of Food Science and Technology, Universiti Putra Malaysia, UPM, Serdang, Selangor, Malaysia. Environmental Monitoring and Assessment, 171, 205-217.

Helfman, G., Collete, B. \& Facey, D. (1997). The Diversity of Fishes. Malden, MA: Blackwell.

Ikem, A. \& Egiebor, N.O. (2005). Assessment of trace elements in canned fishes (mackerel, tuna, salmon, sardines and herrings) marketed in Georgia and Alabama (United States of America), Journal of Food Composition and Analysis, 18, 771-787.

Irwandi, J. \& Farida, O. (2009). Mineral and heavy metal contents of marine fin fish in Langkawi Island, Malaysia, International Food Research Journal, 16, 105-112.

Islam, M.M., Bang, S. Kyoung-Woong, K., Ahmed, M.K. \& Jannat, M. (2010). Heavy metals in frozen and canned marine fish of Korea, J. Sci. Res. 2(3), 549557.

Jaffar, M. \& Ashrafi M. (1988). Selected trace metal concentrations in different tissues of fish from coastal waters of Pakistan (Arabian Sea). Indian Journal of Marine Sciences, 17, 231-234.

Karadede, H., Oymak, S.A. \& Unlu, E. (2004). Heavy metals in mullet, Liza abu, and catfish, Silurus triostegus, from the Ataturk Dam Lake (Euphrates). Turkey Environmental International, 30, 183-188.

Kaladharan, P., Nandakumar, A. \& Valsala, K. K. (2006). Trace metals in the muscle tissue of nine marine fish species from Port Blair and Kochi. Journal of the Marine Biological Association of India, 48, 224-228.

Kamaruzzaman, B.Y., Ong, M.C. \& Rina, S.Z. (2010). Concentration of $\mathrm{Zn}, \mathrm{Cu}$ and $\mathrm{Pb}$ in some selected marine fishes of the Pahang Coastal Waters, Malaysia, American Journal of Applied Sciences 7(3), 309-314.

Kerdthep, P., Tongyonk, L. \& Rojanapantip, L. (2009). Concentrations of cadmium and arsenic in seafood from Muang District, Rayong Province. Journal of Health Research, 23, 179-184.

Khaled, A. (2004). Heavy metals concentrations in certain tissues of five commercially important fishes from El-mex Bay, Alexandria, Egypt, Environmental 
Division. Egyptian Journal of Aquatic Biology and Fisheries, 8, 51-64.

Khattak, M.I., Khattak, M.I. \& Mohibullah, M. (2012). Study of heavy metal pollution in mangrove sediments reference to marine environment along the coastal areas of Pakistan. Pakistan J. Bot., 44(1), 373-378

Khoshnood, Z., Khoshnood, R., Mokhlesi, A., Ehsanpour, M., Afkhami, M. \& Khazaali, A. (2012). Determination of $\mathrm{Cd}, \mathrm{Pb}, \mathrm{Hg}, \mathrm{Cu}, \mathrm{Fe}, \mathrm{Mn}$, $\mathrm{Al}$, As, Ni and $\mathrm{Zn}$ in important commercial fish species in northern of Persian Gulf, Journal of Cell and Animal Biology, 6, 1-9.

Kojadinovic, J., Potier, M., Corre, M.L., Cosson, R.P. \& Bustamante, P. (2007). Bioaccumulation of trace elements in pelagic fish from the Western Indian Ocean. Environmental Pollution, 146, 548-566.

Krishna Kumar, P. K., PIillai, V. K. \& Valsala, K. K. (1990). Bioaccumulation of trace metals by marine flora and fauna near a caustic soda plant (Karwar, India). Indian Journal of Fish, 37, 129-137.

Malakootian, M., Tahergorabi, M., Daneshpajooh, M. \& Amirtaheri, K. (2011). Determination of $\mathrm{Pb}, \mathrm{Cd}$, $\mathrm{Ni}$, and $\mathrm{Zn}$ concentrations in canned fish in Southern Iran, Sacha Journal of Environmental Studies, 1, 94-100.

Meaburn, G.M. (1978). Heavy metal contamination of Spanish mackerel, Scomberomorus maculatus, and king mackerel, S. cavalla. In Proceedings of the mackerel colloquium, March 16, 1978, p. 61-66. Charleston, Lab., SEFSC, Charleston, SC.

Mendil, D., Demirci, Z., Tüzen, M. \& Soylak, M. (2010). Seasonal investigation of trace element contents in commercially valuable fish species from the Black Sea, Turkey. Food and Chemical Toxicology, 48, 865-870

Mol, S. (2011). Levels of selected trace metals in canned tuna fish produced in Turkey. Journal of Food Composition and Analysis, 24, 66-69. https://doi.org/10.1016/j.jfca.2010.04.009.

Mukherjee, D.P. \& Bhupander, K. (2011). Assessment of arsenic, cadmium and mercury level in commonly consumed coastal fishes from Bay of Bengal, India. Food Science and Quality Management, 2, 22246088.

Mukhtar, I. \& Hannan, A. (2012). Constrains on mangrove forests and conservation projects in Pakistan. J Coast Conserv., 16, 51-62. doi: 10.1007/s11852-011-0168-x

Nair, M., Jayalakshmy, K.V., Balachandran, K.K. \& Joseph, T. (2006). Bioaccumulation of toxic metals by fish in a semi-enclosed tropical ecosystem. Environmental Forensics, 7, 197-206.
Nieboer, E., \& Richardson, D.H.S. (1980). The replacement of the nondescript term 'heavy metals' by a biologically and chemically significant classification of metal ions. Environ. Pollut., 1(B), 3-26.

Nisbet, C., Terzi, G., Pilger, O. \& Sarac, N. (2010). Determination of heavy metal levels in fish sample collected from the Middle Black Sea. Kafkas Üniv. Vet. Fak. Der. 16(1), 199-125.

Nor-Hasyimah, A.K., James-Noik- V., The, Y.Y., Lee, C.Y. \& Pearline Ng, H.C. (2011). Assessment of cadmium $(\mathrm{Cd})$ and lead $(\mathrm{Pb})$ levels in commercial marine fish organs between wet markets and supermarkets in Klang Valley, Malaysia. International Food Research Journal, 18, 795-802.

Noreña-Ramirez, D.A., Murillo-Perea, E., Guio-Duque, J.A. \& Méndez-Arteaga, J.J. (2012). Heavy metals $(\mathrm{Cd}, \mathrm{Pb}$ and $\mathrm{Ni})$ in fish species commercially important from Magdalena river, Tolima tract, Colombia. Revista Tumbaga, 2(7), 6176.

Rejomon, G., Dinesh Kumar, P.K. \& Bahulayan, N. (2010). Biogeochemistry of lead in the Eastern Arabian Sea and Western Bay of Bengal. Environmental Forensics, 11, 223-236.

Saei-Dehkordi, S.S. \& Fallah, A.A. (2011). Determination of copper, lead, cadmium and zinc content in commercially valuable fish species from the Persian Gulf using derivative potentiometric stripping analysis. Microchemical Journal, 98, 156162. https://doi.org/10.1016/j.microc.2011.01.001.

Sivaperumal, P., Sankar, T. V. \& Nair, P. G. V. (2007). Heavy metal concentrations in fish, shellfish and fish products from internal markets of India visavis international standards. Food Chemistry, 102, 612-620.

Sobhanardakani, S., Tayebi, L., Farmany, A. \& Charaghi, M. (2011). Analysis of trace elements $(\mathrm{Cu}, \mathrm{Cd}$, and $\mathrm{Zn})$ in the muscle, gill, and liver tissues of some fish species using anodic stripping voltammetry. Environmental Monitoring and Assessment, 184, 6607-6611.

Sofia, S. (2005). Metal contamination in commercially important fish and shrimp species collected from Aceh (Indonesia), Penang and Perak (Malaysia). Master's thesis, Univers Sains Malaysiya, 163 pp.

Sogut, O. \& Percin, F. (2011). Trace elements in the kidney tissue of bluefin tuna (Thunnus thynnus L. 1758) in Turkish seas. African Journal of Biotechnology, 10, 1252-1259.

Srebocan, E., Pompe-Gotal, J., Prevendar-Crnic, A. \& Ofner, E. (2007). Mercury concentrations in captive Atlantic bluefin tuna (Thunnus thynnus) 
farmed in the Adriatic Sea. Veterinarni Medicina, 52, 175-177.

Tariq, J., Jaffar, M. \& Moazzam, M. (1993). Heavy metal concentration in fish, shrimp, seaweed, sediment and water from the Arabian Sea, Pakistan. Marine Pollution Bulletin, 26, 644-7.

Sireli, U.T., Goncuoglu, M., Yıldırım, Y., Gucukoglu, A. \& Cakmak, O. (2006). assessment of heavy metals (Cadmium and Lead) in vacuum packaged smoked fish species (Mackerel, Salmo salar and Oncorhynhus mykiss) marketed in Ankara Turkey. E.U. Journal of Fisheries and Aquatic Sciences, 23, 353-356.

Tuzen, M. (2003). Determination of heavy metals in fish samples of the middle Black Sea (Turkey) by graphite furnace atomic absorption spectrometry. Food Chemisry, 104(2), 835-840.

Tuzen, M. \& Soylak, M. (2007). Determination of trace metals in canned fish marketed in Turkey. Food Chemistry, 101, 1378-1382.

Tuzen, M. (2009). Toxic and essential trace elemental contents in fish species from the Black Sea, Turkey. Food and Chemical Toxicology, 47,1785-1790.

Turkmen, M., Turkmen, A., Tepe, Y., Tore, Y. \& Ates, A. (2009). Determination of metals in fish species from Aegean and Mediterranean seas. Food Chemistry, 113, 233-237. https://doi.org/10.1016/j.foodchem.2008.06.071

Uluozlu, O.D., Tuzen, M., Mendil, D. \& Soylak, M. (2007). Trace metal content in nine species of fish from the Black and Aegean Seas, Turkey. Food Chemistry, 104(2), 835-840.

Underwood, E.J. (1977). Trace elements in human and animal nutrition, 4th edition, Academic Press, New York.
Vijayakumar, P., Lavanya, R., Veerappan, N. \& Balasubramanian, T. (2011). Heavy metal concentrations in three commercial fish species in Cuddalore Coast, Tamil Nadu, India, Journal of Experimental Sciences, 2, 20-23.

Wheeler, A. (1985). The World Encyclopedia of Fishes. London: Macdonald.

Yousuf, F. \& Ahmed, Q. (2010). Heavy metals $(\mathrm{Cu}, \mathrm{Fe}$, $\mathrm{Mn}, \mathrm{Zn}$ ) content in Thunnus tonggol (FamilyScombridae) from Karachi coast. Karachi University Journal of Science, 38, 5-9.

Yousuf, F. \& Ahmed, Q. (2011). Concentration of heavy metals in liver and muscles of fish, Rastrelliger kanagurta, from the coast of Karachi, Pakistan. International Journal of Biology and Biotechnology, 8, 543-550.

Zarei, M., Mollaie, A., Eskandari, M.H., Pakfetrat, S. \& Shekarforoush, S. (2010). Histamine and Heavy Metals Content of Canned Tuna Fish, Global Veterinaria, 5, 259-263.

Received date: 20.05 .2018

Accepted date: 28.07 .2018

\section{*Corresponding author's:}

Quratulan AHMED

The Marine Reference Collection and Resources Centre, University of Karachi, Karachi, 75270 Pakistan.

E-mail: quratulanahmed_ku@yahoo.com

ORCID: https://orcid.org/0000-0002-7597-2483 